\title{
WestVirginiaUniversity
}

THE RESEARCH REPOSITORY @ WVU

Graduate Theses, Dissertations, and Problem Reports

2014

\section{Estimating Ultimate Gas Recovery from Unconventional Gas Reservoir}

Amgd M. Kharabah

Follow this and additional works at: https://researchrepository.wvu.edu/etd

\section{Recommended Citation}

Kharabah, Amgd M., "Estimating Ultimate Gas Recovery from Unconventional Gas Reservoir" (2014). Graduate Theses, Dissertations, and Problem Reports. 7321.

https://researchrepository.wvu.edu/etd/7321

This Thesis is protected by copyright and/or related rights. It has been brought to you by the The Research Repository @ WVU with permission from the rights-holder(s). You are free to use this Thesis in any way that is permitted by the copyright and related rights legislation that applies to your use. For other uses you must obtain permission from the rights-holder(s) directly, unless additional rights are indicated by a Creative Commons license in the record and/ or on the work itself. This Thesis has been accepted for inclusion in WVU Graduate Theses, Dissertations, and Problem Reports collection by an authorized administrator of The Research Repository @ WVU. For more information, please contact researchrepository@mail.wvu.edu. 


\title{
Estimating Ultimate Gas Recovery from Unconventional Gas Reservoir
}

\author{
Amgd M. Kharabah
}

\author{
Thesis Submitted to the \\ College of Engineering and Mineral Resources at \\ West Virginia University \\ In partial fulfillment of the requirements for the degree of \\ Master of Science \\ In \\ Petroleum and Natural Gas Engineering
}

Khashy Aminian, PhD., Chair

Samuel Ameri, M.S.

Dan Della-Giustina, Ph.D.

Department of Petroleum and Natural Gas Engineering

Morgantown, West Virginia

2014

Keywords: Ratio flow rate, Horizontal Well with multiple hydraulic fractures, Shale Gas

Copyright 2014 Amgd M. Kharabah 
All rights reserved

INFORMATION TO ALL USERS

The quality of this reproduction is dependent upon the quality of the copy submitted.

In the unlikely event that the author did not send a complete manuscript and there are missing pages, these will be noted. Also, if material had to be removed, a note will indicate the deletion.

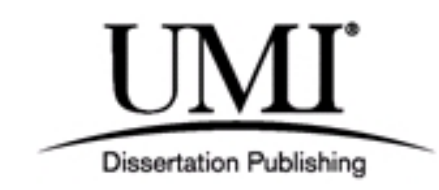

UMI 1555067

Published by ProQuest LLC (2014). Copyright in the Dissertation held by the Author.

Microform Edition () ProQuest LLC.

All rights reserved. This work is protected against unauthorized copying under Title 17, United States Code

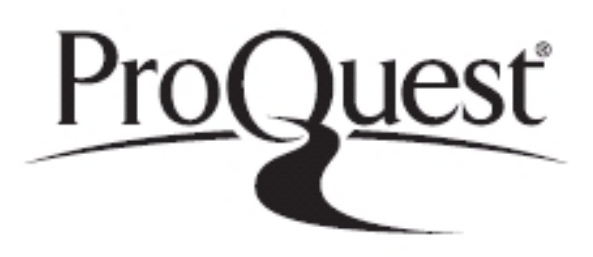

ProQuest LLC.

789 East Eisenhower Parkway

P.O. Box 1346

Ann Arbor, MI 48106 - 1346 


\section{ABSTRACT \\ Estimating Ultimate Gas Recovery from Unconventional Gas Reservoir \\ AMGD M. KHARABAH}

The rise in natural gas global demand is the major factor influencing the increase in exploration and development of the unconventional gas resources. Most of the unconventional gas reservoirs have very low permeability and are not able to produce an economic flow rate without stimulation treatments. The application of the advanced technologies including a horizontal drilling and hydraulic fracturing has been responsible for the economic development of unconventional gas resources. Horizontal wells with multiple hydraulic fracture treatments have proven to be an effective method for development of shale reservoirs. However, there is no simple technique available for the predicting the ultimate gas recovery from the shale reservoir due to complex interaction of horizontal well, hydraulic fracture, and natural fracture present in the shale. Additionally, most shale reservoir such as Marcellus shale have a limited production history available and the long term production is not well established. The objective of this study is to estimate the ultimate gas recovery from horizontal wells with multiple hydraulic fractures completed in a shale formation based on the early production history.

Production history and other field data were utilized in this study to develop a model for prediction of the long term production and ultimate gas recovery from the shale reservoirs. The model was then utilized to develop a correlation between early production and the ultimate gas recovery. The impact of the reservoir and hydraulic fracture properties on the correlation was investigated. The number and the half-length of the hydraulic fracture were found to have a significant impact on the correlation. 


\section{ACKNOWLEDGEMENTS}

This thesis is the result of my momentous journey in obtaining a master's degree in Petroleum and Natural Gas Engineering (PNGE) at West Virginia University (WVU). I would like to express my gratitude towards certain outstanding individuals for helping make this thesis a success.

My sincere gratitude is to my academic advisor, Dr. Kashy Aminian, for his support during my studies at WVU. I really appreciate his help, patience, and guidance during my stay at WVU. His assistance was invaluable to me and undoubtedly a memorable experience. Looking to the future, one of my goals is becoming as good an advisor to my mentees as Dr. Kashy has been to me.

In addition, I would also like to extend my appreciation to Professor Sam Ameri, Chairman of the PNGE Department, for his endless support during the course of my stay at WVU. Being more than just a professor to me, his advice always motivated me to thoroughly complete my research work. I remain extremely indebted to Professor Sam Ameri for his continuous support and relentless assistance.

In closing, I want to thank Dr. Dan Della-Giustina for taking the time to be involved in the examining committee. His valued contribution to this review is highly appreciated.

I would like to express my special thanks to the staff of the petroleum and natural gas department. I really appreciate the help and support of my colleagues and friends especially my friend Mohamed El-sgher who has gladly helped me out during my study at West Virginia University. 


\section{DEDICATION}

I am grateful to God for making my dream a reality by obtaining a Master's degree in Petroleum \& Natural Gas Engineering at West Virginia University. This thesis is dedicated to my lovely parents, Huda and Mohammad. Mom and dad, I love you both very much. Most importantly, I would like to dedicate my master work to my gorgeous wife Marwa and my little angel, my daughter Ghazal and all my family members. Thank you for your help, encouragements, motivation and endless love during my life. 


\section{TABLE OF CONTENTS}

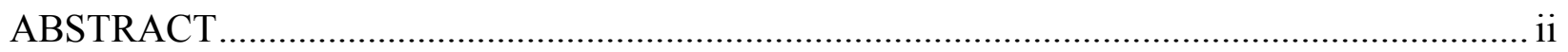

Estimating Ultimate Gas Recovery from Unconventional Gas Reservoir...................................... ii

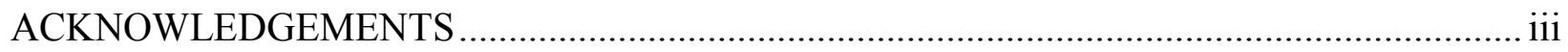

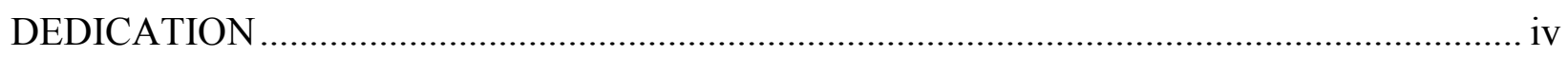

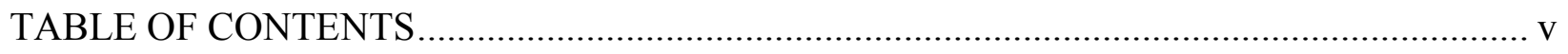

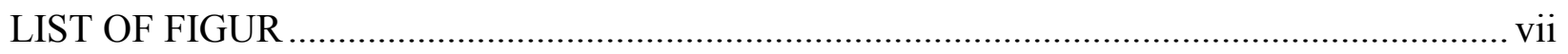

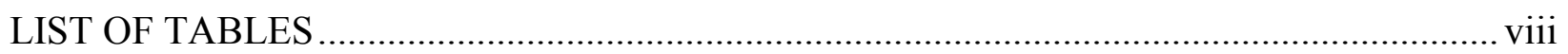

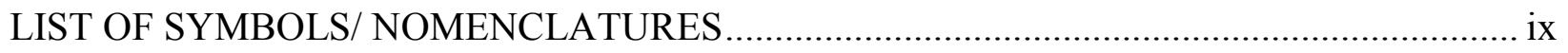

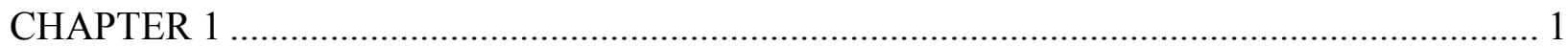

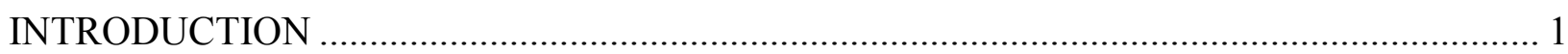

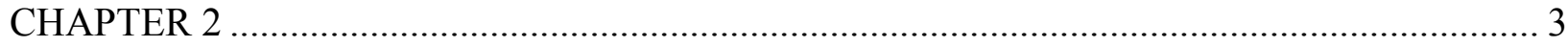

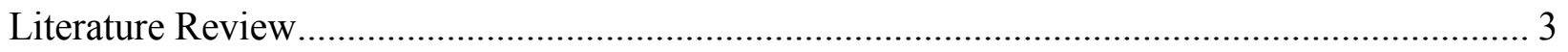

2-1 Conventional \& Unconventional Reservoirs ................................................................ 3

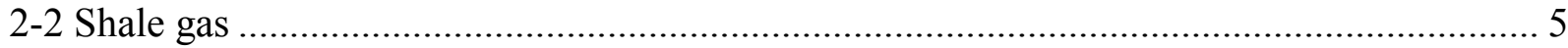

2-3 Horizontal Drilling ............................................................................................... 7

2-4 Hydraulic Fracturing ..................................................................................................... 9

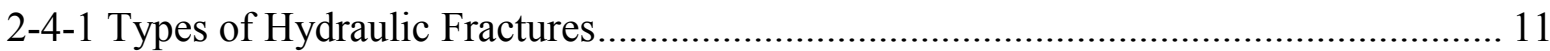

2-4-2 Dimensionless Fracture Conductivity ...................................................................... 13

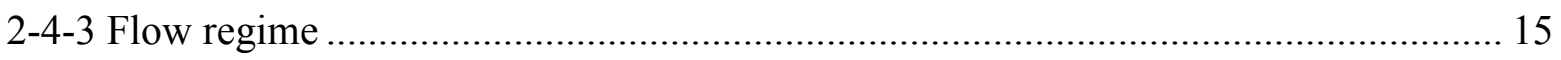

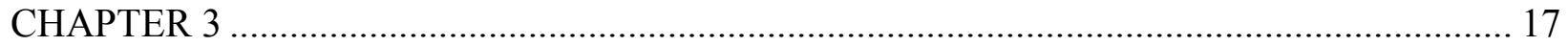

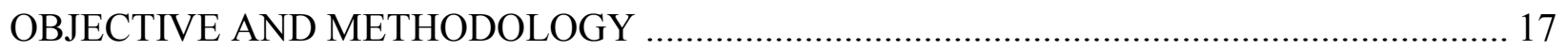

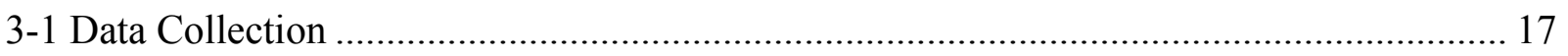

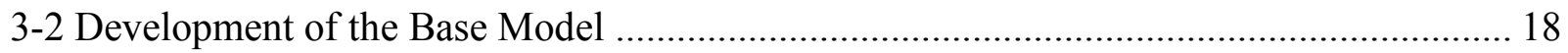

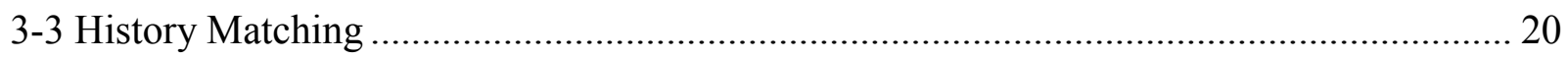

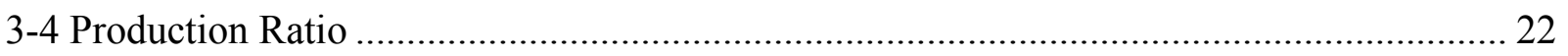

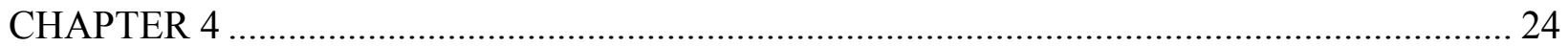

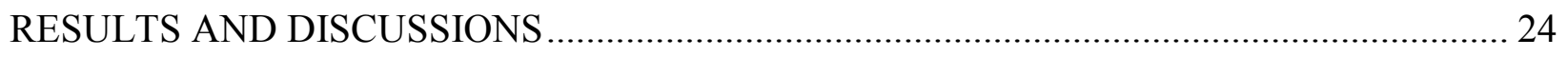

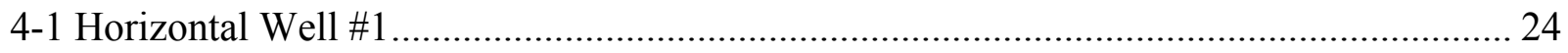




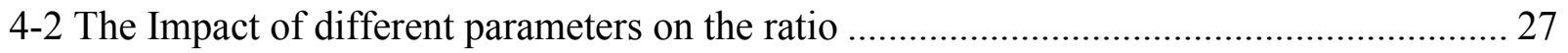

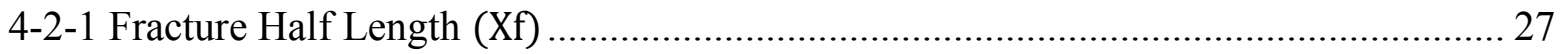

4-2-2 Fracture permeability (kf) and number of fractures ......................................... 28

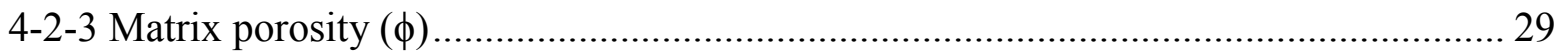

4-3 Evaluation the reliability of the correlation ............................................................... 30

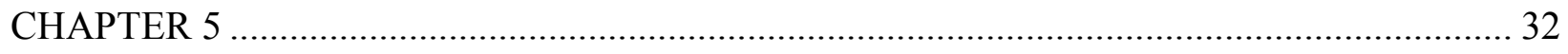

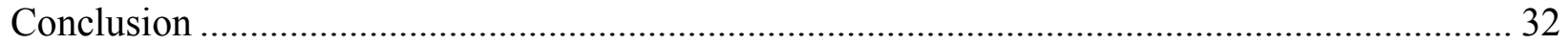

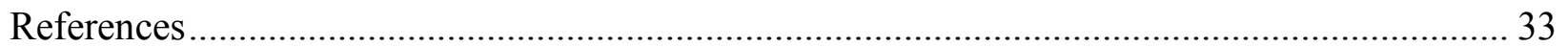

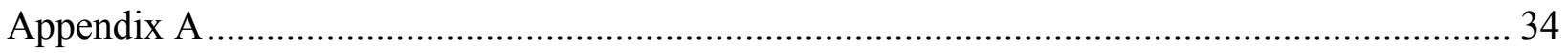




\section{LIST OF FIGURES}

Figure 2-1 Resource Triangle (modified from Masters, 1979) ................................................ 4

Figure 2-2 U.S. Natural Gas Production in TCF/year, 1990-2040 (EIA, 2011).......................... 5

Figure 2-3 Free Gas in Matrix, Free Gas in Fractures and Adsorbed Gas in the Solid (Song and

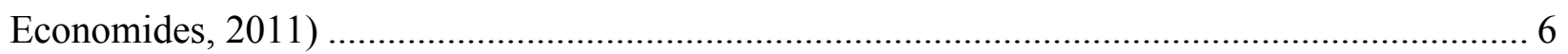

Figure 2-4 Gas Adsorption/Desorption Isotherm (Song and, Economides, 2011) ..................... 7

Figure 2-5 Horizontal well intersecting the Marcellus formation (geology, 2012) .................... 8

Figure 2-6 Hydraulic Fracturing Process (Tschirhart,2005) .............................................. 10

Figure 2-7 Comparison of Production rate between Transverse and Longitudinal fractures in shale (Soliman, 1999). .................................................................................................... 12

Figure 2-8 Comparison of cumulative production between Transverse and Longitudinal fractures in shale (Soliman, 1999) ................................................................................................... 12

Figure 2-9 Infinite-conductivity and finite-conductivity fractures ...................................... 14

Figure 2-10 Pressure versus time graph showing the various time periods (www.fekete.com)... 15

Figure 2-11 Fracture linear flow regime occurs during early time (www.fekete.com) ............... 16

Figure 2-12 Bi-linear flow regimes during middle time period (www.fekete.com)................... 16

Figure 3-1 History matching and prediction for horizontal well $\# 1$...................................... 21

Figure 3-2 Predicted production rate closely matched the actual data for horizontal well\#1 ....... 21

Figure 3-3 Production ratio for the first year ................................................................. 22

Figure 3-4 Production ratio for the second year ................................................................ 23

Figure 4-1 Final history matching for well\#1 ............................................................. 26

Figure 4-2 Comparison of the model predictions for different fracture half-length and actual

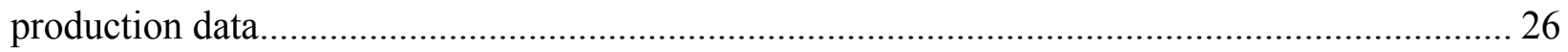

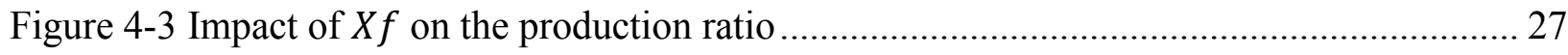

Figure 4-4 Impact of fracture permeability and number of fractures on the ratio ..................... 28

Figure 4-5 Impact of matrix porosity on the ratio........................................................ 29

Figure 4-6 History matching and prediction for horizontal well $\# 2$...................................... 30

Figure 4-7 History matching and prediction for horizontal well \#3 ...................................... 31

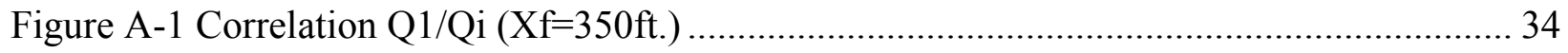

Figure A-2 Correlation Q2/Qi (Xf=350ft.) ....................................................................... 34

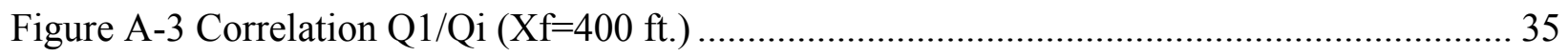

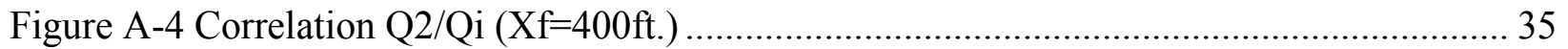

Figure A-5 Correlation Q1/Qi (Xf=500 ft.) ................................................................... 36

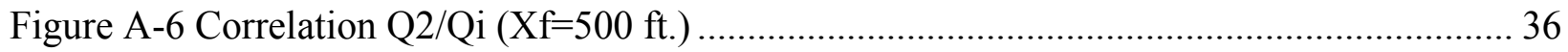




\section{LIST OF TABLES}

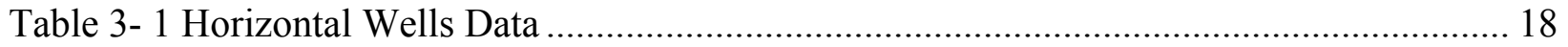

Table 3-2 Base Model Parameters ............................................................................................ 19

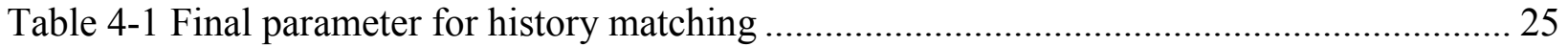

Table 4-2 Results of the correlation predictions for Well \#2 ............................................... 30

Table 4-3 Results of the correlation predictions for Well \#3................................................. 31 


\section{LIST OF SYMBOLS/ NOMENCLATURES}

$k=$ formation permeability, md

$k_{m}=$ matrix permeability, md

$\emptyset_{m}=$ matrix porosity, $\%$

$X_{f}=$ fracture half length, $\mathrm{ft}$

$k_{f}=$ hydraulic fracture permeability, md

$\emptyset_{f}=$ hydraulic fracture porosity, $\%$

$W_{f}=$ hydraulic fracture width, in

$P_{l}=$ Langmuir pressure, psia

$V_{a d s}=$ the gas volume can be absorbed by a rock of unit mass, $\mathrm{SCF} /$ ton

$\mathrm{V}_{l}=$ Langmuir volume, $\mathrm{SCF} /$ ton

$T=$ temperature, ${ }^{\circ} \mathrm{F}$

$F_{c d}=$ dimensionless fracture conductivity

$h=$ thickness, $\mathrm{ft}$.

$r_{e}=$ drainage radius, $\mathrm{ft}$.

$r_{w}=$ wellbore radius, $\mathrm{ft}$.

$P_{w f}=$ bottom hole pressure, $\mathrm{psi}$

$P_{i}=$ reservoir pressure, $\mathrm{psi}$ 


\section{CHAPTER 1}

\section{INTRODUCTION}

Unconventional gas reservoir is a term commonly used to refer to a low permeability reservoir that produces mainly dry natural gas. Horizontal drilling technology is used to increase drainage area and productivity of the low permeability reservoirs. In the last several years, using horizontal drilling technology in oil exploration, development, and production operations has grown rapidly. It is becoming a larger percentage of the development wells. Horizontal drilling with multiple hydraulic fracturing has become the key techniques to achieve economic production from unconventional reservoirs. The hydraulic fracturing is a stimulation technique which is used to increase permeability in a formation.

Horizontal wells with multiple hydraulic fractures have recently become the key technology to achieve economic production from shale gas reservoirs. However, the production data available from these horizontal wells only reflect the short-term recovery. Production ratio can be used to estimate the long-term recovery for the horizontal wells. This thesis will be a new study on the production analysis of the Marcellus Shale using reservoir simulation and history matching techniques.

Unconventional reservoirs play huge roles in hydrocarbon production in the United States. Marcellus shale that is found in the Appalachians has shown remarkable promise in the past few years. Marcellus shale formation is expected to be an important contributor to the natural gas supply of the United States. Unconventional reservoirs such as Marcellus shale present several challenges compared to conventional reservoirs. The first challenge is that shale 
formations have dual porosity or naturally fractured formations. This naturally fractured reservoir contains two storage volumes for hydrocarbons; the rock matrix and natural fractures. The adsorbed gas is considered as the second challenge in the unconventional reservoirs. Adsorbed gas is contained within organic material in the shale. These two major differences between conventional gas reservoirs and shale gas reservoirs can have a noticeable impact on production performance. 


\section{CHAPTER 2}

\section{Literature Review}

\section{2-1 Conventional \& Unconventional Reservoirs}

Conventional reservoirs are essentially medium to high permeability reservoirs. Therefore, they can produce at the commercial flow rate without stimulation treatments or any special recovery process. The unconventional reservoirs cannot be produced at an economic flow rate. The low permeability reservoirs such as shale gas, tight sand, and coal bed methane require stimulation treatments to improve the permeability. Thus, horizontal drilling and hydraulic fracturing are technologies for production from the low permeability reservoirs at an economic flow rate.

The concept of the resource triangle is very useful in understanding the distribution of gas reservoirs and the factors which affect them was used by Master's, (1979). Figure 2-1 illustrates the resource triangle for conventional and unconventional reservoir. Conventional reservoirs are small in size and easy to develop, but often hard to find. The unconventional reservoirs with large volumes of oil or gas in place are generally much more difficult to develop. Unconventional reservoirs need high technology and are much more costly to develop. Due to gas demand and increasing gas prices, the unconventional gas reservoirs can be developed to meet the demand. 


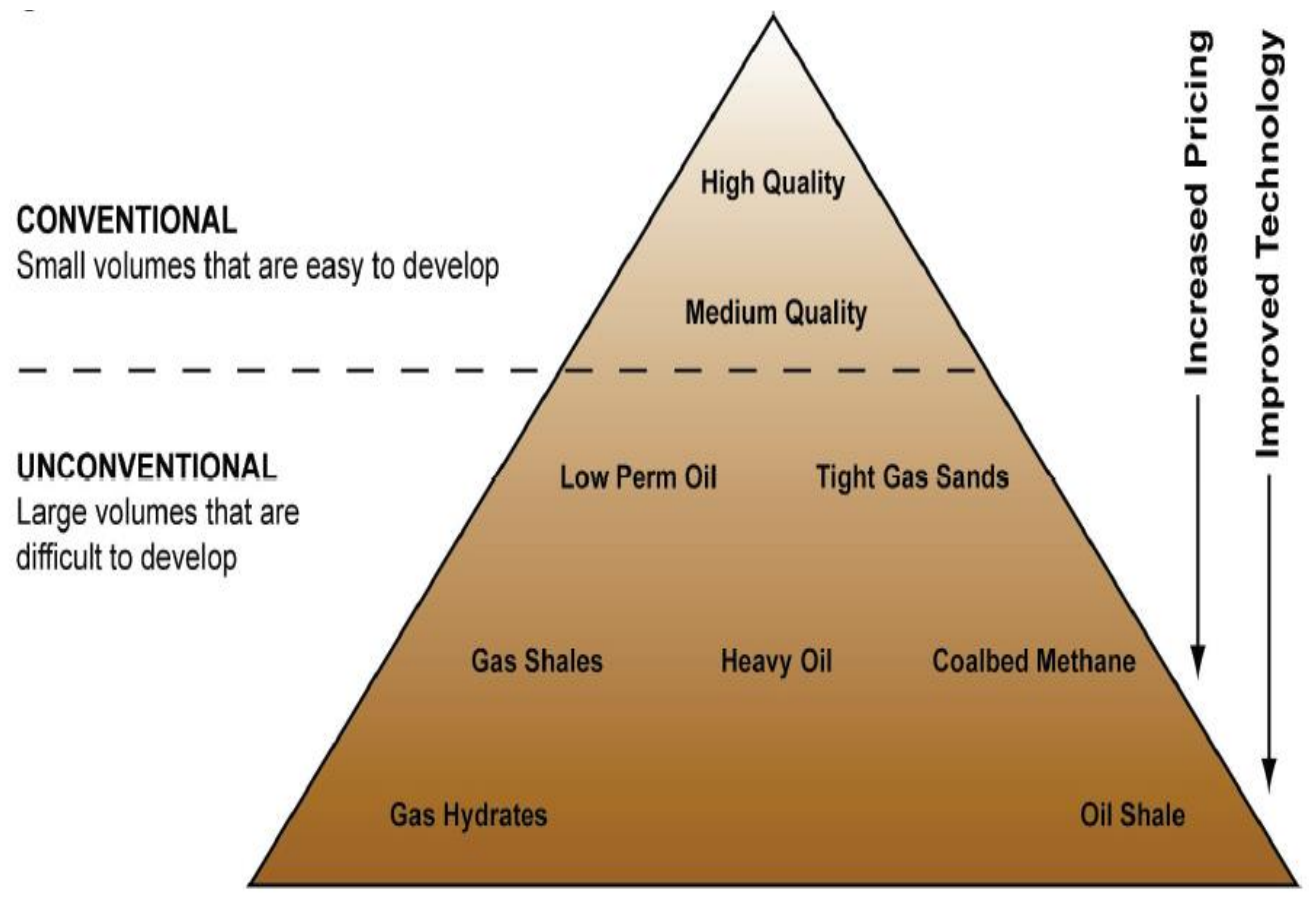

Figure 2-1 Resource Triangle (modified from Masters, 1979)

Figure 2-2 from Energy Information Administration (EIA), illustrates the historical production and projections for natural gas from 1990-2035, while total domestic natural gas production will grow from 21.0 TCF in 2009 to 26.3 TCF in 2035, shale gas production will grow to $12.2 \mathrm{TCF}$ in 2035 , when it will make up 47 percent of total U.S. production-up considerably from the 16 percent share in 2009.

The production of shale gas has grown dramatically; production of natural gas from shale gas in the United States grew by an average of 17 percent per year from 2000 to 2006. Early successes in shale gas production occurred primarily in the Barnett Shale of north central Texas. By 2006, successful shale gas operations in the Barnett shale, improvements in shale gas recovery technologies, and attractive natural gas prices encouraged the industry to accelerate its 
development activity in other shale plays. The combination of two technologies- horizontal drilling and hydraulic fracturing- made it possible to produce shale gas economically, and from 2006 to 2010 U.S. shale gas production grew by an average of 48 percent per year (AOE 2011).

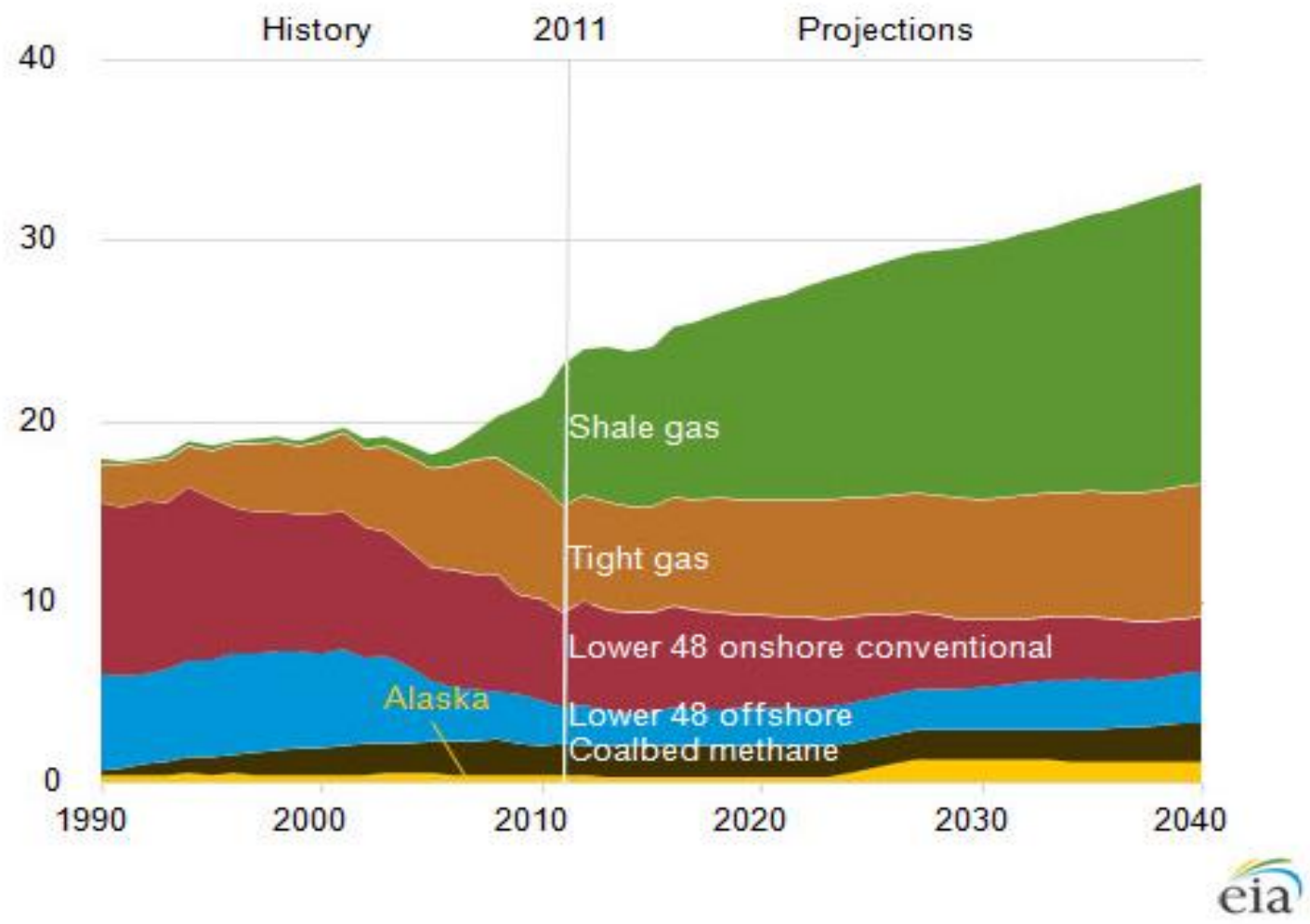

Figure 2-2 U.S. Natural Gas Production in TCF/year, 1990-2040 (EIA, 2012)

\section{2-2 Shale gas}

Shale is a type of clay or mud that can easily split into layers. These layers were compressed by formation pressure or other geological circumstances and turned into a fine-grained sedimentary rock. Shale formations function as source rocks and seals for conventional reservoirs. Gas migrates from source rock to sandstone or carbonate reservoirs. There, gas is accumulated and trapped in the 
sandstone resulting in a gas reservoir. Shale gas reservoir is defined as highly organic formation having permeability ranging from $0.1 \mathrm{mD}$ to $10-7 \mathrm{mD}$. (Siripatrachai and. Ertekin, 2011)

In shale gas reservoirs, gas can be stored in three forms: free gas in matrix pores which has the majority of gas storage in the formation but with a very low permeability, free gas in fractures with a higher permeability but low storage capacity, and adsorbed gas on the surface of shale as it illustrates in Figure 2-3 below. Adsorbed gas can be primarily characterized by two parameters: Langmuir Volume $\left(\mathrm{V}_{l}\right)$ and Langmuir Pressure $\left(\mathrm{P}_{l}\right)$. Gas produced from shale is mostly methane, but some are wet gas.

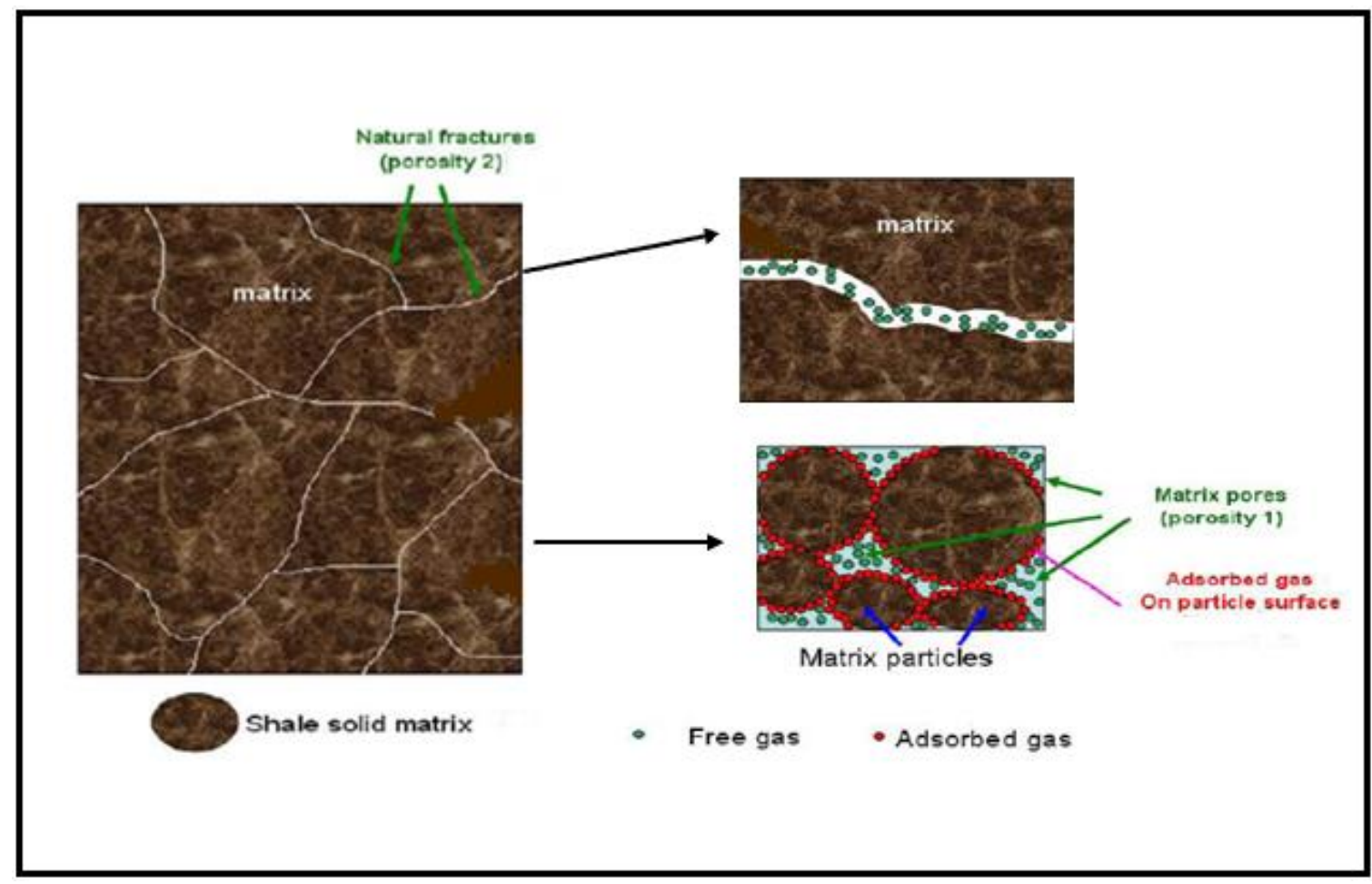

Figure 2-3 Free Gas in Matrix, Free Gas in Fractures and Adsorbed Gas in the Solid (Song and Economides, 2011) 
The adsorption / desorption mechanism is governed by Langmuir isotherm where two properties are associated with: Langmuir volume or gas content $\left(\mathrm{VL}_{\mathrm{L}}\right)$ and Langmuir pressure $\left(\mathrm{PL}_{\mathrm{L}}\right)$. The mathematic expression of this model is:

$$
V_{a d s}=\frac{V_{L} P}{P_{L}+P} \ldots \ldots \ldots \ldots \ldots
$$

Langmuir Pressure and Langmuir Volume are needed to describe the adsorption/desorption of a particular reservoir rock. Figure 2-4 (Song and Economides, 2011) is a typical Langmuir isotherm indicating the amount of gas adsorbed as pressure increases or desorbed as pressure decreases.

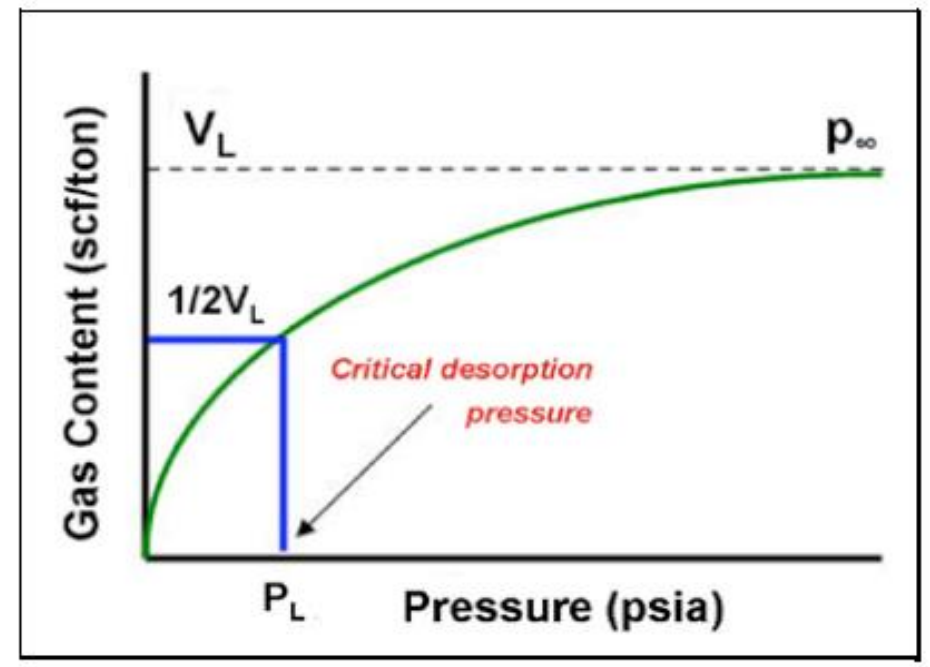

Figure 2-4 Gas Adsorption/Desorption Isotherm (Song and, Economides, 2011)

\section{2-3 Horizontal Drilling}

Horizontal drilling is the process of drilling a well from the surface to a subsurface location just above the target oil or gas reservoir called the "kickoff point", then deviating the well bore from the vertical plane around a curve to intersect the reservoir at the "entry point" with a near horizontal inclination, and remaining within the reservoir until the desired bottom 
hole location is reached. This technique helps to penetrate a maximum distance of gas-bearing rock and a maximum number of vertical rock fractures. Figure 2-5 shows how a horizontal well intersects a number of hydraulic fractures in a Marcellus zone.

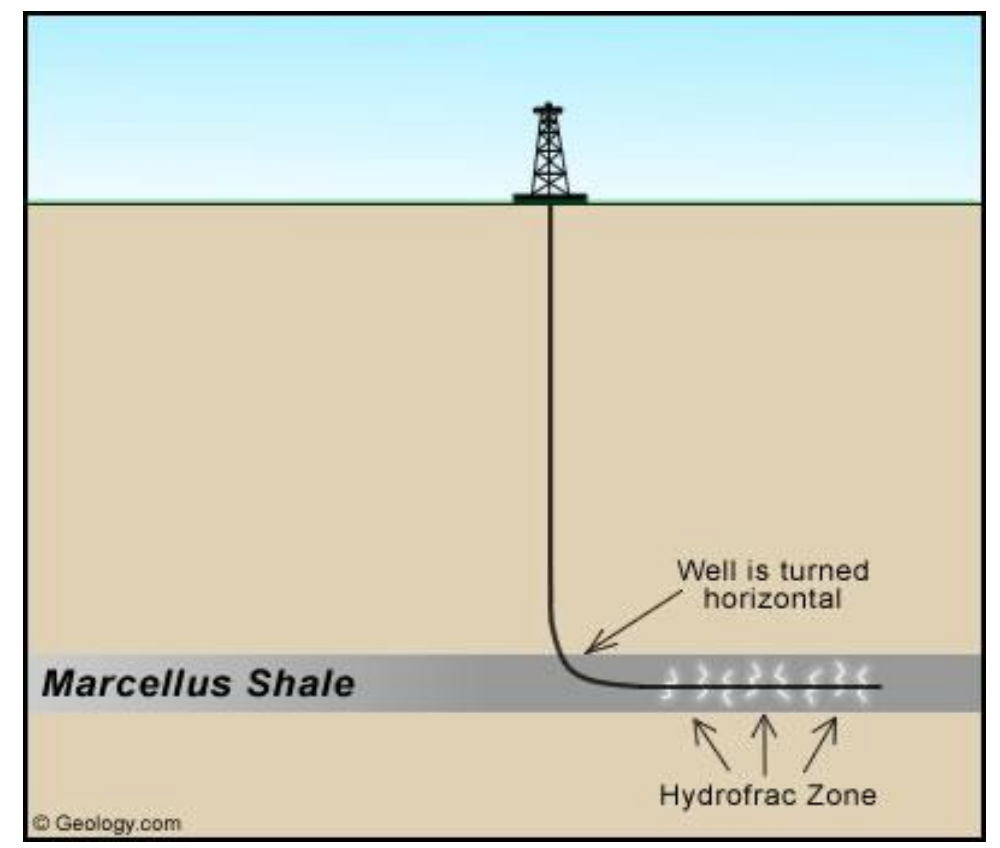

Figure 2-5 Horizontal well intersecting the Marcellus formation (geology, 2012)

Horizontal wells are preferable more than vertical wells when drilling in a Marcellus shale reservoir which is going to be hydrofraced because of two reasons. The first reason is that, the natural fractures in Marcellus shale are vertical and when a vertical well is drilled in this reservoir, very few vertical fractures are intersected. However, the horizontal well intersects many of the vertical fractures. Another major reason is that a hydraulically fractured horizontal well will most likely outperform a hydraulically fractured vertical well in a shale reservoir.

Although, horizontal wells are preferred to vertical wells for the Marcellus formation, it is important to know that they are more expensive than vertical wells. An average newly drilled 
horizontal well costs about 1.5 to 2.5 times more than a vertical well (Joshi, 1988). On the other hand, the productivity of the horizontal well is 2 to 5 times larger than the vertical well (Joshi, 1988). Thus, for the given economic gas rate limit, horizontal wells could be produced with up to half to one-third reservoir pressure as compared to the reservoir pressure required for economic production from a vertical well (Joshi, 1988).

\section{2-4 Hydraulic Fracturing}

Well stimulation is a well intervention performed on oil and gas wells to increase production by improving the flow of hydrocarbon from reservoir to wellbore. There are mainly two well stimulation methods

- Matrix Acidizing

- Hydraulic Fracturing.

Matrix Acidizing is a stimulation technique in which acid solution (HCL, mixture of HCL \& HF) is injected into a formation to dissolve some minerals. The process of hydraulic fracturing is very vital in unconventional reservoirs (For example, Marcellus shale) if it is to be commercially produced. Hydraulic fracturing is used to create a flow path in a gas reservoir that can facilitate the fluid flow of natural gas to a producing well.

Marcellus shale has low connectivity and restricted pore volume that impedes the flow of natural gas through the reservoir. Therefore, it is usually fractured by injecting a fluid containing sand or other proppant under specific pressure to efficiently create fractures in the rock through which the natural gas can easily flow. 
According to Schlumberger, slick-water (a low viscosity water based fluid) and proppant can be used for deeper high-pressure Marcellus shale with increased production, while nitrogen foamed fracturing fluid is more applicable to shallower low-pressure shale. Caution is necessary to contain the fractures within the specified gas reservoir to avoid intersecting adjoining aquifers that would introduce excess water into the gas producing zone. In order to increase the success rate of the hydraulic fracture significantly and have an effective stimulation, a long and conductive fracture will have to be created. This is because the shale reservoirs have ultra-low permeability. Figure 2-6 illustrates how hydraulic fracturing process is implemented.

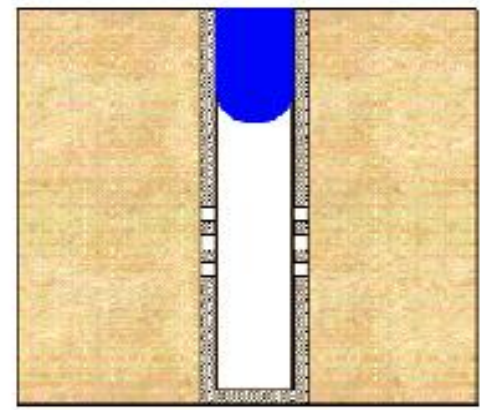

a. Fluid is pumped down well.

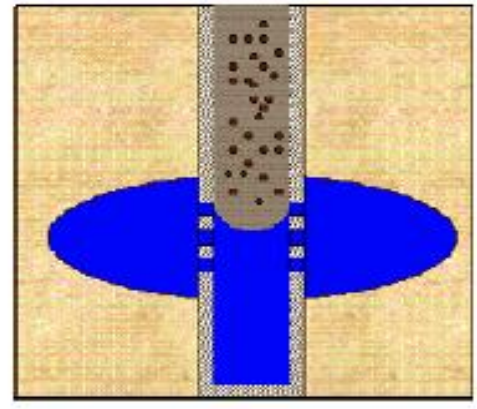

d. Proppant is transported with viscous fluid into fracture.

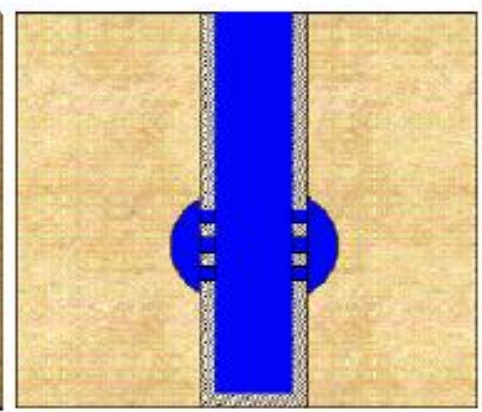

b. Hydraulic pressure of fluid initiates a fracture in the reservoir.

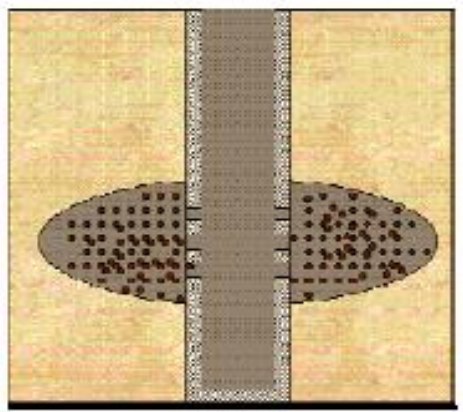

e. Viscous fluid uniformly transports fluid deeply into the fracture.

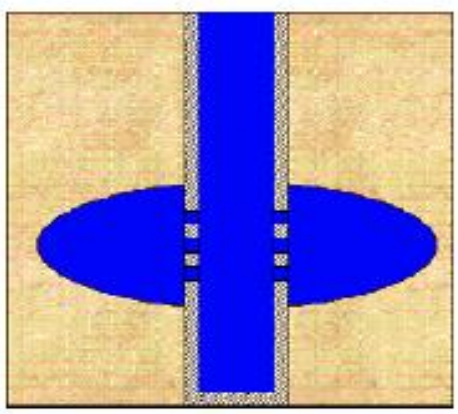

c. Fracture begins propagating into reservoir.

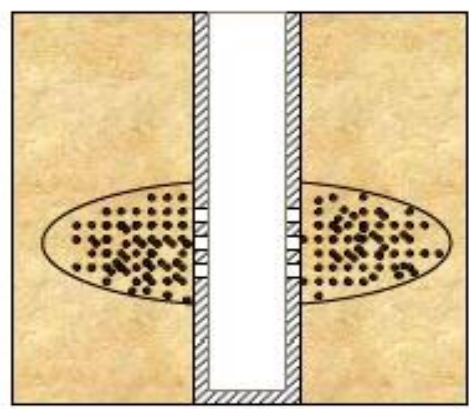

f. Viscous fluid breaks and is allowed to flow back out of well. The formation closes upon proppants resulting in a long conductive fracture.

Figure 2-6 Hydraulic Fracturing Process (Tschirhart, 2005) 


\section{2-4-1 Types of Hydraulic Fractures}

There are two different types of hydraulic fractures that can be created in a reservoir. These fractures are determined by the direction of the stress field (vertical or normal to the horizontal minimum stress) in the producing formation. If the horizontal well is drilled parallel to the minimum horizontal stress, it is expected that the fractures created will be perpendicular to the horizontal well, thereby, creating a transverse well while, the other limiting case can be generated if a horizontal well is drilled perpendicular to the minimum horizontal stress, creating a longitudinal fracture. Here, the fractures created usually are parallel to the horizontal well.

Longitudinal fractured wells perform massively in high permeability reservoirs, however, for Marcellus shale reservoirs, transverse fractured horizontal well are very attractive as they are more productive than longitudinal fractured horizontal well when compared with one another in the same reservoir and conditions. Figures 2-7 and 2-8 show the comparison of the production rate and cumulative production between transverse and longitudinal fractures, respectively. 


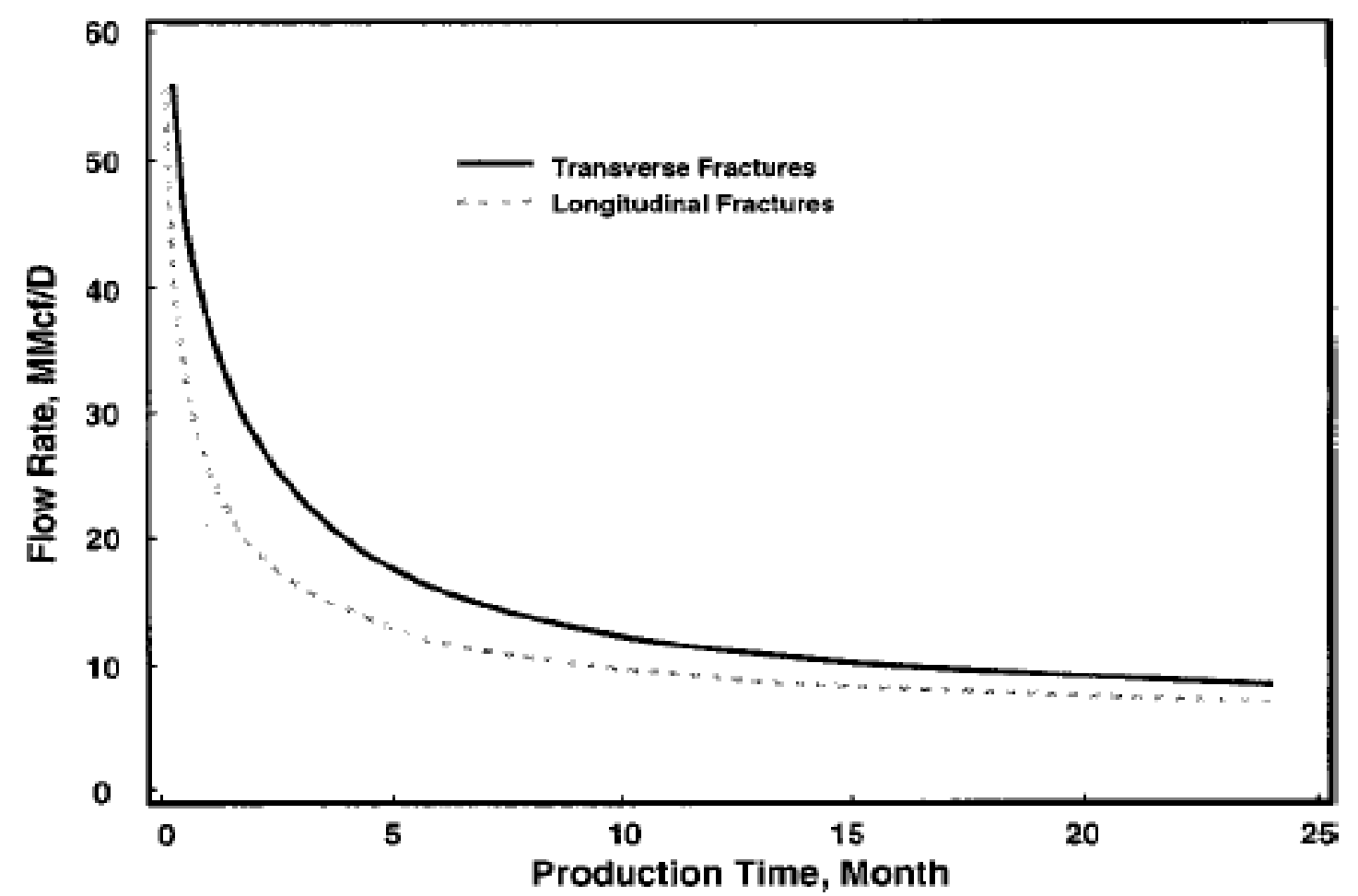

Figure 2-7 Comparison of flow rate between Transverse and Longitudinal fractures in shale (Soliman, 1999).

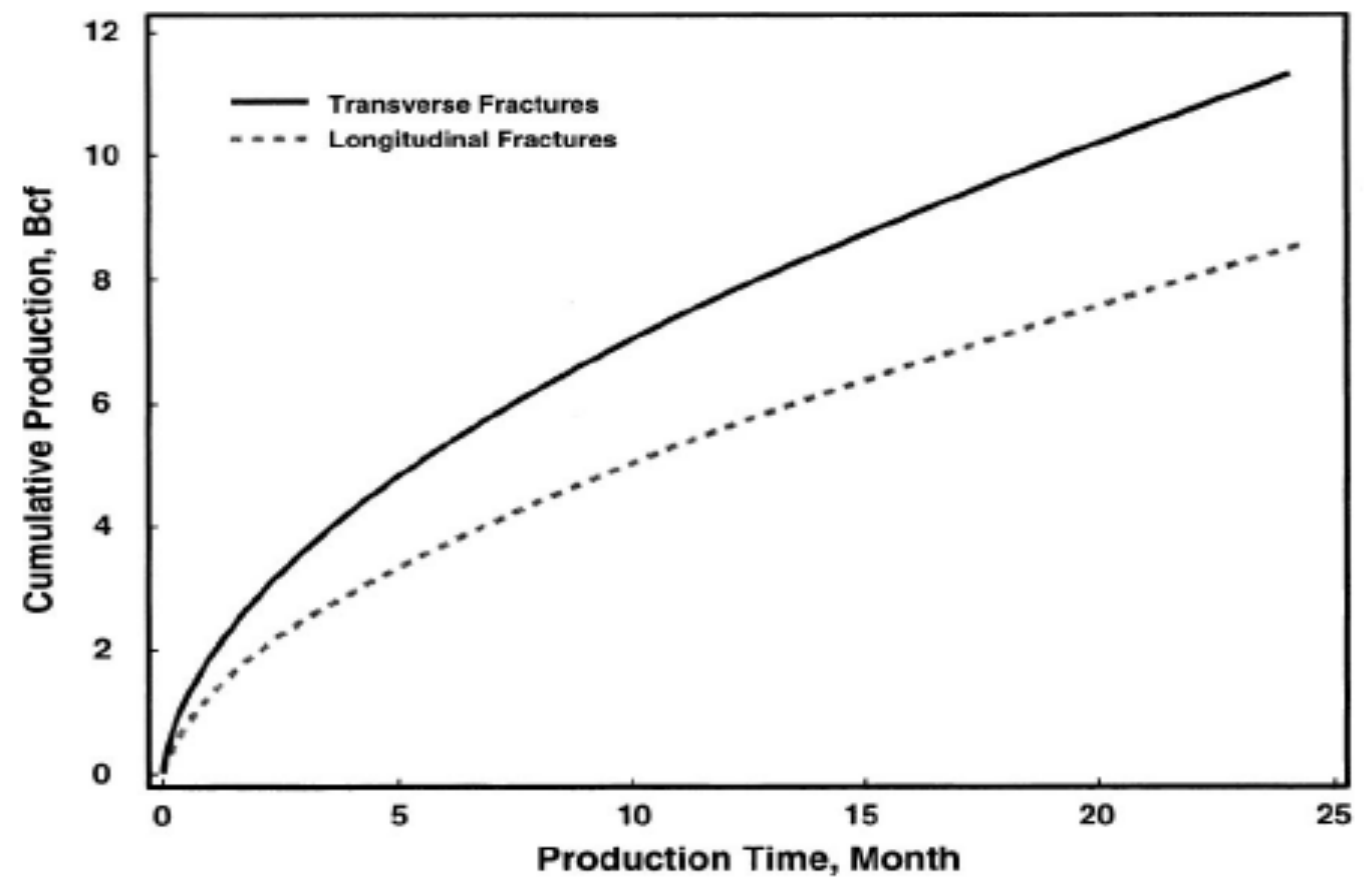

Figure 2-8 Comparison of cumulative production between Transverse and Longitudinal fractures in shale (Soliman, 1999) 


\section{2-4-2 Dimensionless Fracture Conductivity}

The placement of a horizontal well in the formation can impact the stimulation of the well significantly. In reality, there is a difference between the horizontal wells and the lateral wells. These horizontal wells take about 75 to 85 degree angles using the upward or downward dips and assume the trend of the formation. Talking about producing from a hydraulically fractured horizontal well includes very important variables like reservoir permeability, reservoir pressure, wellbore length, well drainage area and fracture orientation (in-situ stress and fracture direction).

Hydraulic fracturing is often used in low permeability reservoirs which is not capable of reaching economic production rates. This is very different in character to the naturally fractured reservoirs that are classified as having a dual porosity. In general, hydraulic fractures are characterized by four variables: fracture half-length $\left(X_{f}\right)$, fracture width $(w)$, formation permeability $(k)$ and proppant pack permeability $\left(k_{f}\right)$. These four characteristics make up the dimensionless fracture conductivity. Dimensionless fracture conductivity along with fold of increase (FOI) in productivity are two very important factors to be considered when creating a hydraulic fracture. Dimensionless fracture conductivity less than 10 is considered poor, while a value between 10 and 50 is considered to be good, and any value beyond 50 is considered to have excellent dimensionless fracture conductivity (Gidley, 1989).

$$
C_{f}=\frac{k_{f} w}{k X_{f}} \ldots \ldots \ldots \ldots \ldots(2)
$$

Unlike natural fractures, hydraulic fractures are almost entirely vertical generally and they cut through the thickness of a reservoir, thereby, increasing the chances of hitting the pay zone. 
- Infinite-conductivity fracture

Assumes that there is no pressure drop along the fracture

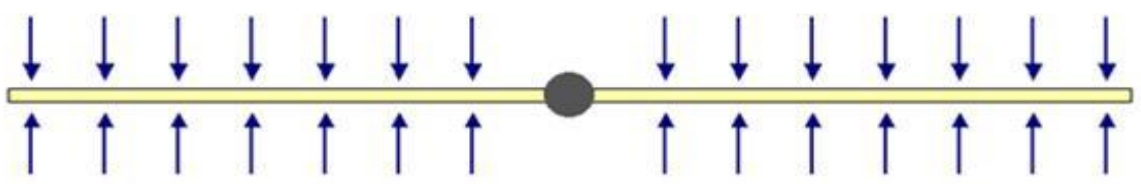

- Finite-conductivity fracture

Assumes that there is pressure drop along the fracture.

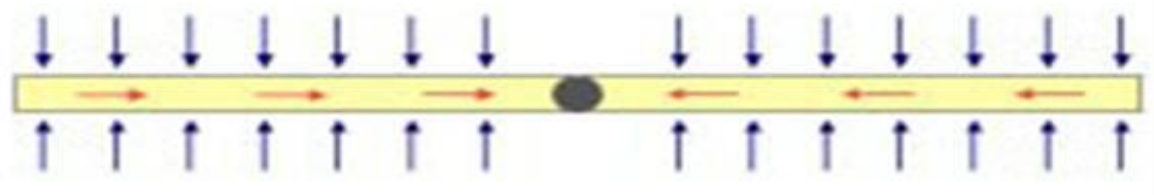

Figure 2-9 Infinite-conductivity and finite-conductivity fractures

Unlike natural fractures, hydraulic fractures are almost entirely vertical generally and they cut through the thickness of a reservoir, thereby, increasing the chances of hitting the pay zone. 


\section{2-4-3 Flow regime}

There are four different flow regimes that can occur in a hydraulically fractured reservoir which are fracture linear flow, bilinear flow, reservoir linear flow and pseudo-radial flow (www.fekete.com). Figure 2-10 shows different time periods that exist in the life of the shale gas reservoir.

Legends:

E.T: Early Time

Middle Time

Transition period

Late Time: Pseudo steady state (P.S.S) or Steady State (S.S)

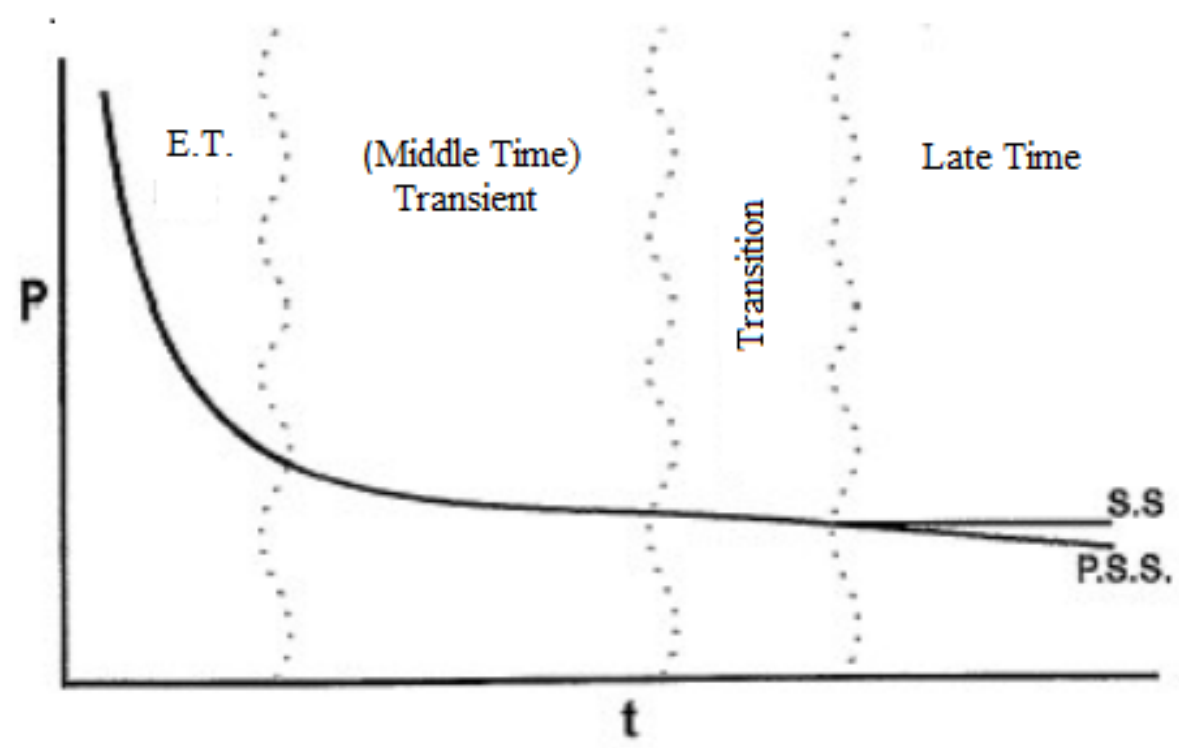

Figure 2-10 Pressure versus time graph showing the various time periods (www.fekete.com). 
The flow regime starts out early with a fracture linear flow as shown in Figure 2-11, which lasts for a very short time before advancing to the bilinear flow during the mid-time in the reservoir. During the bilinear flow regime, two linear flows occur simultaneously where one flow is a linear flow within the fracture and the other is a linear flow from the formation toward the fracture (www.fekete.com). The bilinear flow regime gives an estimate of Dimensionless fracture conductivity. Figure 2-12 illustrates the bilinear flow regime. The reservoir linear flow toward the fracture occurs when fracture has infinite conductivity. The pseudo- radial flow regime takes a long period of time to occur and only does if there is no boundary effect. The pseudo-radial analysis provides an estimation of formation permeability in the radial direction.

Finally, pseudo steady state flow appears when pressure transient reaches the outer boundaries and the outer boundaries are no flow boundaries.

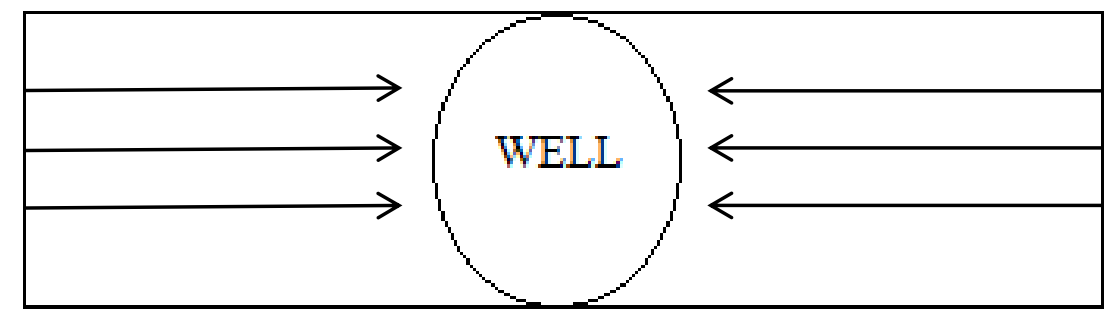

Figure 2-11 Fracture linear flow regime occurs during early time (www.fekete.com)

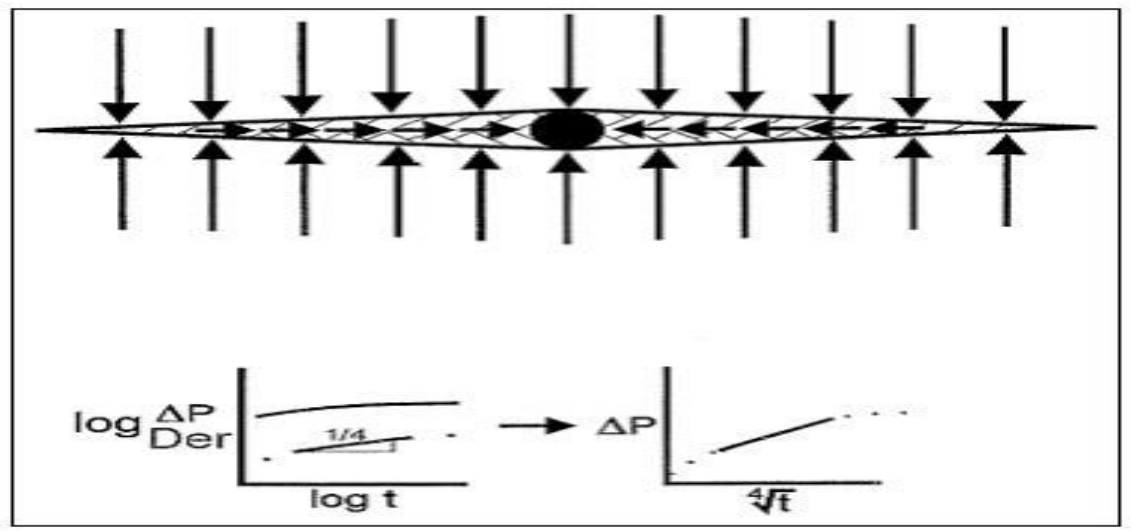

Figure 2-12 Bi-linear flow regimes during middle time period (www.fekete.com). 


\section{CHAPTER 3}

\section{OBJECTIVE AND METHODOLOGY}

The primary objective of this research was to estimate the ultimate gas recovery from horizontal wells with multiple hydraulic fractures in shale formation by using early production history. In order to accomplish these objectives the following procedures were followed:

1) A base model was developed to predict the long term production behavior of a Marcellus shale reservoir.

2) The model was utilized to develop a correlation between the early production and ultimate gas recovery form a Marcellus shale reservoir.

3) The impacts of various reservoir parameters including fracture half length $\left(X_{f}\right)$, fracture permeability $\left(k_{f}\right)$ and matrix porosity $(\phi)$ on the correlation between the early production and ultimate gas recovery were investigated.

4) To evaluate the reliability of the correlation, the predicted ultimate gas recoveries for 2 horizontal Marcellus shale wells based on the actual production data using the correlation were compared against the predicted ultimate gas recoveries from the history matched models.

\section{3-1 Data Collection}

All of the necessary production data for the Marcellus Shale wells was obtained from West Virginia Geological Survey database available on-line. The completion records were also obtained from various sources. There were more than 51 horizontal wells in Marcellus Shale for which some information was available through West Virginia Geological Survey database. The production data 
for majority of these horizontal wells were unavailable. In addition, some of the well had production data which exhibited a lot of fluctuations. This can be for many reasons including changing bottomhole pressures and equipment problems. For this particular study, 3 horizontal wells in Upshur and Marshall Counties that had a long and smooth production history were selected. Table 3-1 summarizes the information for the selected wells.

Table 3- 1 Horizontal Wells Data

\begin{tabular}{|c|c|c|c|c|c|c|}
\hline Well & $\begin{array}{c}\text { API } \\
\text { Number }\end{array}$ & $\begin{array}{c}\text { Permit } \\
\text { Number }\end{array}$ & County & $\begin{array}{c}\text { Horizontal } \\
\text { Length, ft. }\end{array}$ & $\begin{array}{c}\text { Rock } \\
\text { Pressure, psi }\end{array}$ & $\begin{array}{c}\text { Number of } \\
\text { Frac Stages }\end{array}$ \\
\hline 1 & 4709703527 & 3527 & Upshur & 3000 & 3000 & 8 \\
\hline 2 & 4709703516 & 3516 & Upshur & 1812 & 3000 & 5 \\
\hline 3 & 4705101092 & 1092 & Marshall & 2727 & 3000 & 7 \\
\hline
\end{tabular}

\section{3-2 Development of the Base Model}

The base model is an essential part of this study because it will provide the starting point for successful history matching. The length and width of the reservoir was selected based on the length of horizontal lateral. The reservoir thickness was obtained for some of horizontal wells using the "Pay Zone" data from the West Virginia Geological Survey database.

The natural permeability and natural porosity were assumed based on the typical characteristics of the Marcellus Shale. It should be noted that the natural fracture and matrix permeability in vertical (z) direction was assumed to be $1 / 10$ of the permeability in horizontal ( $\mathrm{x}$ and y) direction. Table 3-2 summarizes the base model parameters for Well\#1 that were used in this study. 
Table 3-2 Base Model Parameters

\begin{tabular}{|c|c|c|}
\hline \multicolumn{3}{|c|}{ Base Model Parameters } \\
\hline \multicolumn{2}{|l|}{ Reservoir Parameters } & \\
\hline Depth & 7000 & $f t$. \\
\hline Thickness & 75 & $f t$. \\
\hline \multicolumn{3}{|c|}{ Rock Properties } \\
\hline Porosity type & Dual & \\
\hline Matrix Porosity, $\phi_{m}$ & 0.05 & fraction \\
\hline Matrix Permeability, $k_{x}$ & 0.0002 & $m d$ \\
\hline Matrix Permeability, $k_{y}$ & 0.0002 & $m d$ \\
\hline Matrix Permeability, $k_{z}$ & 0.00002 & $m d$ \\
\hline Fracture Porosity, $\phi_{f}$ & 0.005 & fracture \\
\hline Fracture Permeability, $k_{f x}$ & 0.002 & $m d$ \\
\hline Fracture Permeability, $k_{f y}$ & 0.002 & $m d$ \\
\hline Fracture Permeability, $k_{f z}$ & 0.0002 & $m d$ \\
\hline \multicolumn{3}{|c|}{ Hydraulic Fracture Properties } \\
\hline Number of frac stages & 8 & \\
\hline Half Length & 500 & $f t$. \\
\hline Hydraulic Fracture Permeability & 20000 & $m d$ \\
\hline width & 0.01 & in. \\
\hline Top of Fracture & 7000 & $f t$. \\
\hline Bottom of Fracture & 7075 & $f t$. \\
\hline \multicolumn{3}{|l|}{ Constrains } \\
\hline$P_{w f}$ & 500 & psi \\
\hline \multicolumn{3}{|c|}{ Fluid Properties } \\
\hline Gas Gravity & 0.8 & \\
\hline $\mathrm{CO}_{2}$ Mole Percent & 0 & $\%$ \\
\hline $\mathrm{N}_{2}$ Mole Percent & 0 & $\%$ \\
\hline $\mathrm{H}_{2} \mathrm{O}$ Mole Percent & 0 & $\%$ \\
\hline \multicolumn{3}{|l|}{ Adsorption } \\
\hline Gas Diffusion Coefficient & 1 & $f t^{2} / d a y$ \\
\hline Sorption Pressure & 62 & day \\
\hline Langmuir Pressure & 635 & psia \\
\hline Langmuir Pressure & 0.08899 & Mscf/ton \\
\hline Rock Density & 150 & $l b / f t^{3}$ \\
\hline
\end{tabular}


Typical properties were also assigned to hydraulic fracture. The hydraulic fracture properties generally impact the initial production rate. For example, increasing the permeability of the hydraulic fracture would yield a significantly higher initial production rate. The impact of fracture half-length is however more significant and influences production performance for longer period of time.

Minimum Bottom-hole pressure $\left(P_{w f}\right)$ was assumed to be 500 psia. The value for Langmuir pressure $\left(P_{l}\right)$ and Langmuir volume $\left(V_{l}\right)$ have been defined as it showed in Table 3-2. Langmuir volume $\left(V_{l}\right)$ is the maximum gas volume which can be adsorbed. Langmuir pressure $\left(P_{l}\right)$ represents the pressure at which the gas storage capacity equals one half of the maximum storage capacity.

\section{3-3 History Matching}

History matching was initiated with the base model and the final match was achieved by varying the key parameters such as reservoir drainage area, fracture half-length, matrix permeability, natural fracture permeability and the flowing bottom-hole pressure. In this part of the study, history match was achieved for horizontal well.

Figure 3-1 shows the results of the history matching for horizontal well. Production data for two years (2008 and 2009) was used for history matching by changing parameters. Subsequently, the matched model was used to predict the production for the following three years (2010, 2011 and 2012) to verify accuracy and reliability of the matched model. The predicted production rate closely matched the actual data as it can be seen in Figure 3-2. These results confirmed the reliability of the matched model. 


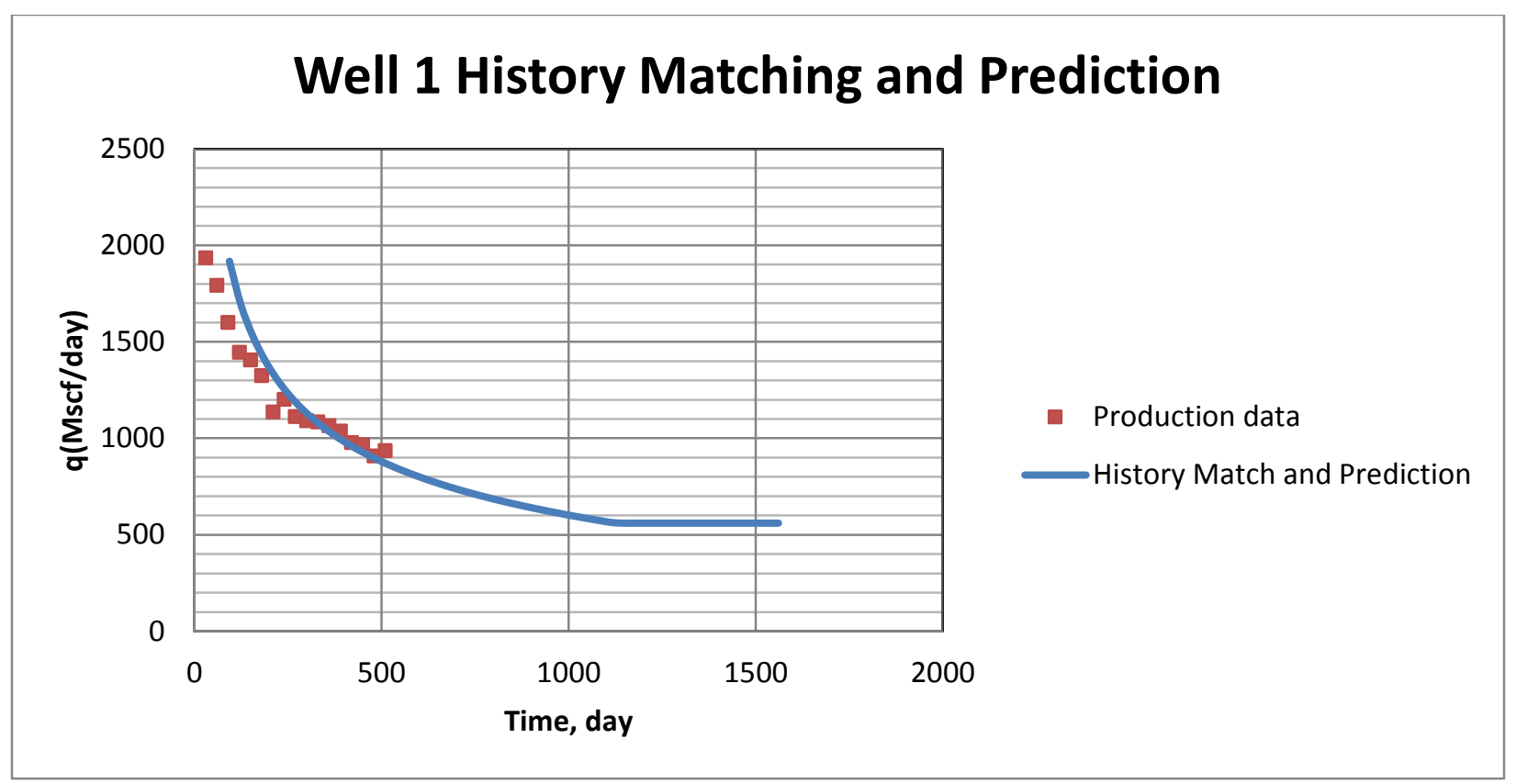

Figure 3-1 History matching and prediction for horizontal well\#1

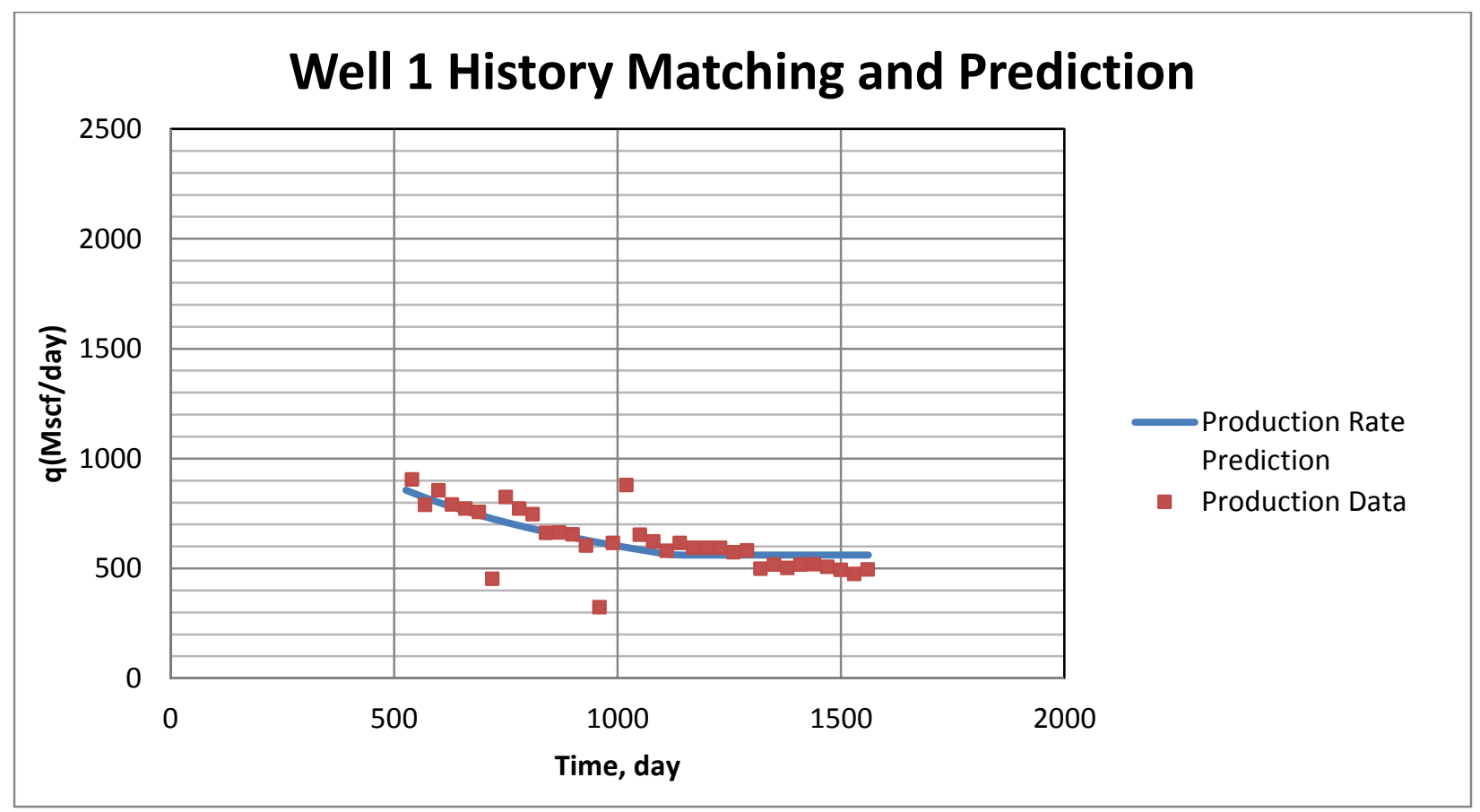

Figure 3-2 Predicted production rate closely matched the actual data for horizontal well\#1 


\section{3-4 Production Ratio}

The production ratio between late production and the first two years for different fracture half-length was calculated in order to find a correlation that help to estimate the recovery in unconventional gas reservoirs. Figure 3-3 and 3-4 illustrate this correlation for well\#1 $\left(X_{f}=\right.$ $350 \mathrm{ft}$.) for the first and the second year respectively. Figures for the rest of the $X_{f}$ values are in appendix A.

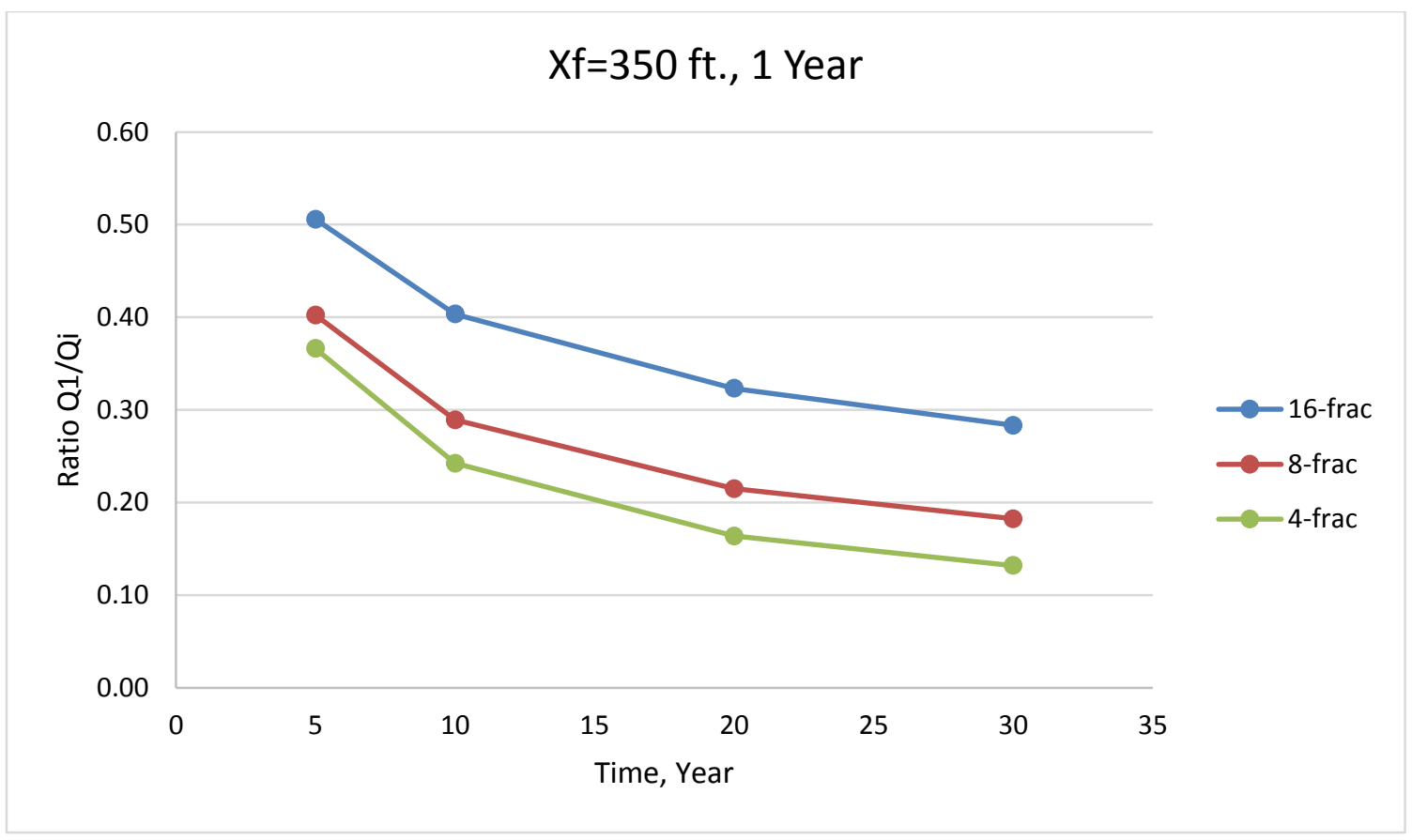

Figure 3-3 Production ratio for the first year 


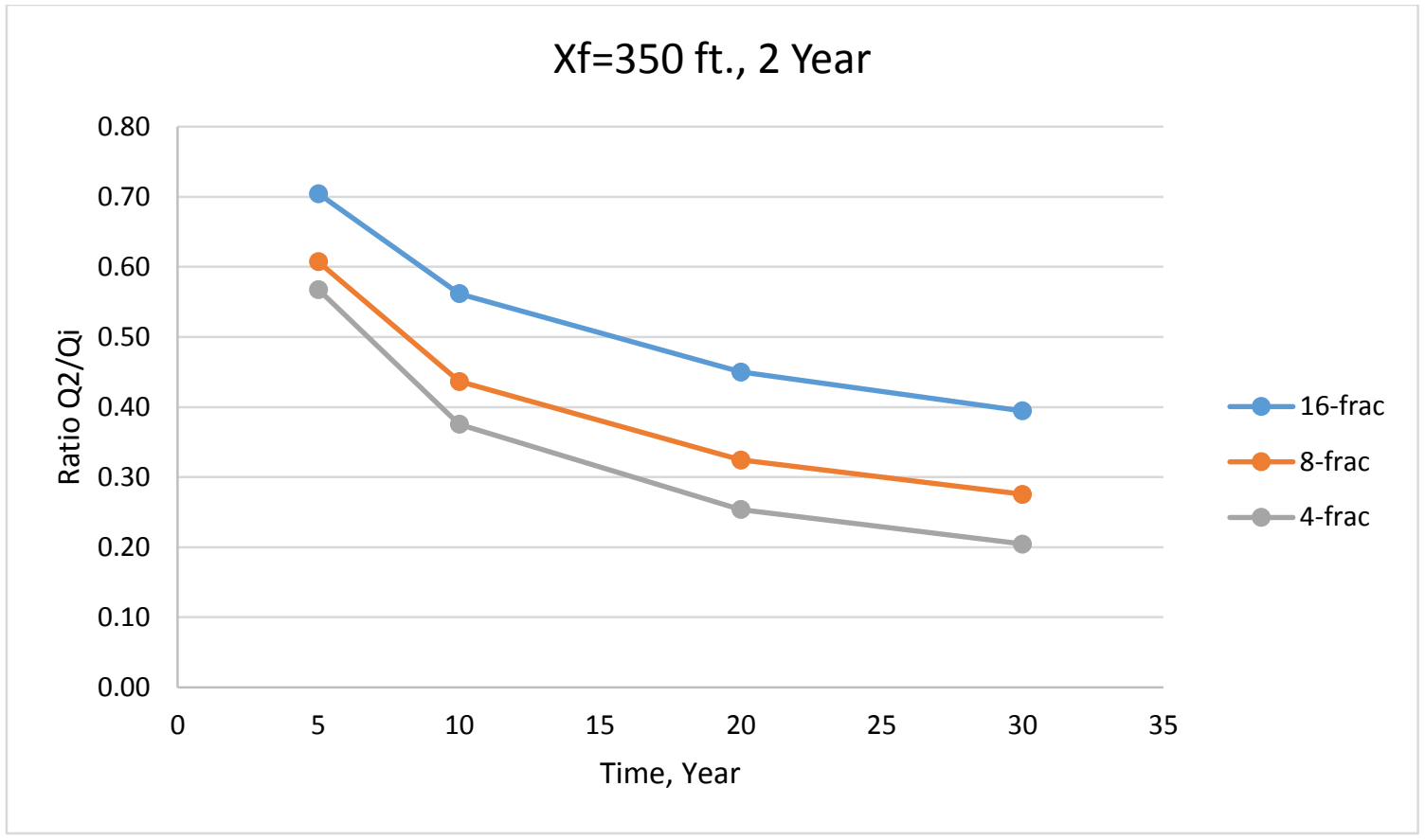

Figure 3-4 Production ratio for the second year 


\section{CHAPTER 4}

\section{RESULTS AND DISCUSSIONS}

\section{4-1 Horizontal Well \#1}

This well is located in Upshur County. The thickness of this well is about $75 \mathrm{ft}$. it has been taken from thickness map of Upshur County. In addition, the length of this reservoir is about $3000 \mathrm{ft}$. which is provided from well data section of West Virginia University Geological Survey. As a result the rectangular drainage area for this reservoir is assumed to be $4000 \times 2000 \mathrm{ft}^{2}$ in dimensions. The initial reservoir pressure was 3000 psia. Table 4-1 shows the final parameter for history matching.

Different parameter has been changed to get a history match for horizontal well\#1. Figure 41 illustrates the final history matching. To obtain a good history match for this well, fracture half length $\left(X_{f}\right)$ was reduced from $500 \mathrm{ft}$. to $400 \mathrm{ft}$. fracture half-length has huge impact on the production. If fracture half-length increases, the production will increase as it illustrates in Figure 42. Moreover, the natural fracture permeability was reduced from $0.002 \mathrm{md}$ to $0.001 \mathrm{md}$ to get history

matching. The permeability of the hydraulic fracture has been decreased from 10,000 md to 20,000 md. The hydraulic fracture permeability generally impacts the initial production rate.

The well has 8 hydraulic fracture stages and the spacing between each fracture is about 500 $\mathrm{ft}$. and the location of the horizontal well is at the center of the rectangular reservoir. 
Table 4-1 Final parameter for history matching

\begin{tabular}{|c|c|c|}
\hline \multicolumn{3}{|c|}{ Well \#1 after Matching } \\
\hline \multicolumn{3}{|c|}{ Base Model Parameters } \\
\hline \multicolumn{2}{|l|}{ Reservoir Parameters } & \\
\hline Depth & 7000 & $f t$. \\
\hline Thickness & 75 & $f t$. \\
\hline \multicolumn{3}{|c|}{ Rock Properties } \\
\hline Porosity type & Dual & \\
\hline Matrix Porosity, $\phi_{m}$ & 0.05 & fraction \\
\hline Matrix Permeability, $k_{x}$ & 0.0002 & $m d$ \\
\hline Matrix Permeability, $k_{y}$ & 0.0002 & $m d$ \\
\hline Matrix Permeability, $k_{z}$ & 0.00002 & $m d$ \\
\hline Fracture Porosity, $\phi_{f}$ & 0.005 & fraction \\
\hline Fracture Permeability, $k_{f x}$ & 0.001 & $m d$ \\
\hline Fracture Permeability, $k_{f y}$ & 0.001 & $m d$ \\
\hline Fracture Permeability, $k_{f z}$ & 0.0001 & $m d$ \\
\hline \multicolumn{3}{|c|}{ Hydraulic Fracture Properties } \\
\hline Number of frac stages & 8 & \\
\hline Half Length & 400 & $f t$. \\
\hline Hydraulic Fracture Permeability & 10000 & $m d$ \\
\hline width & 0.01 & in. \\
\hline Top of Fracture & 7000 & $f t$. \\
\hline Bottom of Fracture & 7075 & $f t$. \\
\hline \multicolumn{3}{|l|}{ Constrains } \\
\hline$P_{w f}$ & 500 & psi \\
\hline \multicolumn{3}{|c|}{ Fluid Properties } \\
\hline Gas Gravity & 0.8 & \\
\hline $\mathrm{CO}_{2}$ Mole Percent & 0 & $\%$ \\
\hline $\mathrm{N}_{2}$ Mole Percent & 0 & $\%$ \\
\hline $\mathrm{H}_{2} \mathrm{O}$ Mole Percent & 0 & $\%$ \\
\hline \multicolumn{3}{|l|}{ Adsorption } \\
\hline Gas Diffusion Coefficient & 1 & $f t^{2} / d a y$ \\
\hline Sorption Pressure & 62 & day \\
\hline Langmuir Pressure & 635 & psia \\
\hline Langmuir Pressure & 0.08899 & Mscf/ton \\
\hline Rock Density & 150 & $l b / f t^{3}$ \\
\hline
\end{tabular}




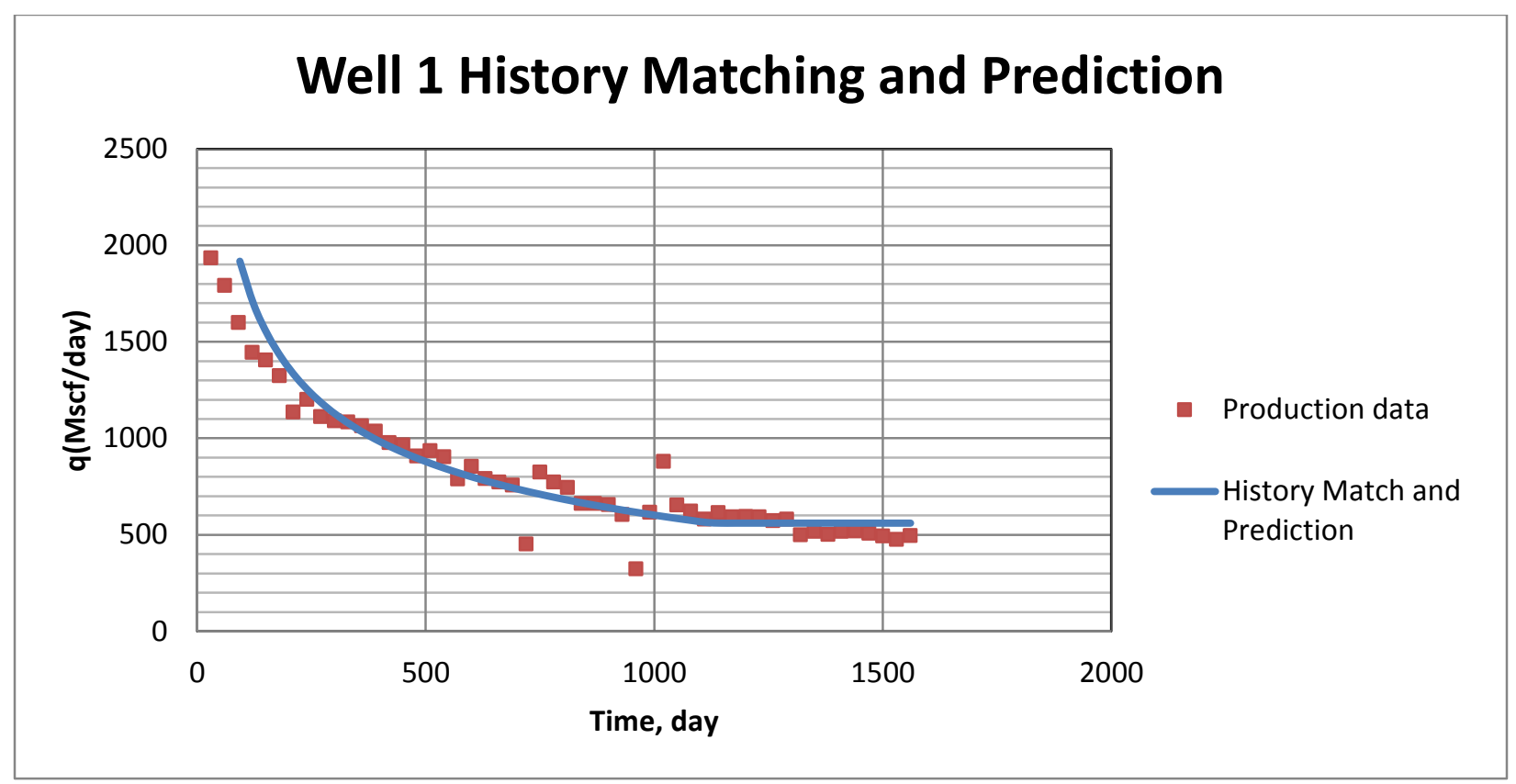

Figure 4-1 Final history matching for well\#1

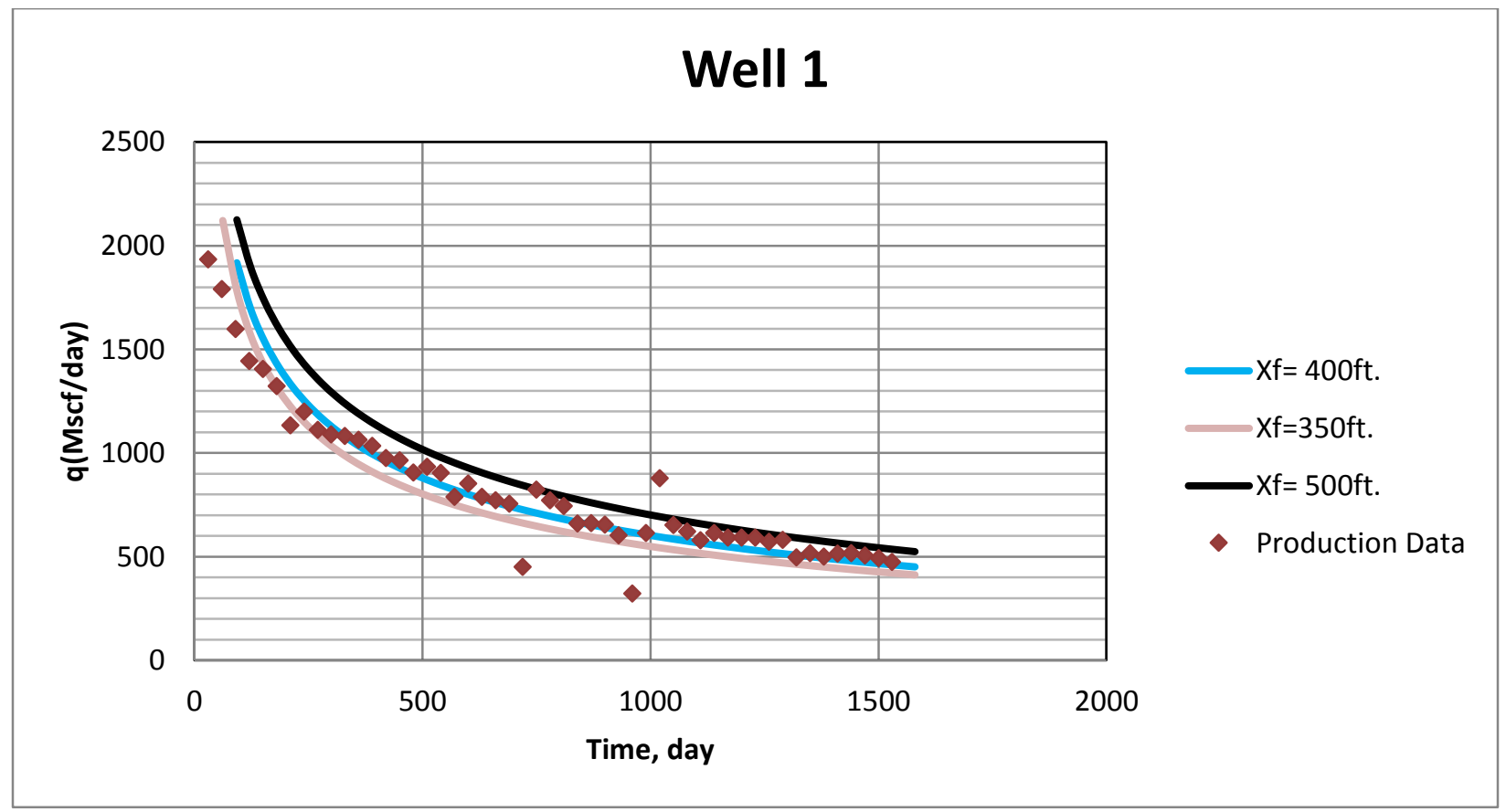

Figure 4-2 Comparison of the model predictions for different fracture half-length and actual production data 


\section{4-2 The Impact of different parameters on the ratio}

In order to come up with a good correlation to estimate the recovery from the early production data, the impact of different parameters was investigated. This investigation included fracture half length, fracture permeability, number of fractures and matrix porosity.

\section{4-2-1 The Impact of the Fracture Half Length $\left(X_{f}\right)$}

In the early period of production the $\left(X_{f}\right)$ value does not affect the production since the production is coming from the near drainage area. However, late production will increase as the fracture half-length value increases because at that time, the gas will be produced from far bigger drainage area. Figure 4-3 illustrates the impact of different value of $X_{f}$ on the production ratio.

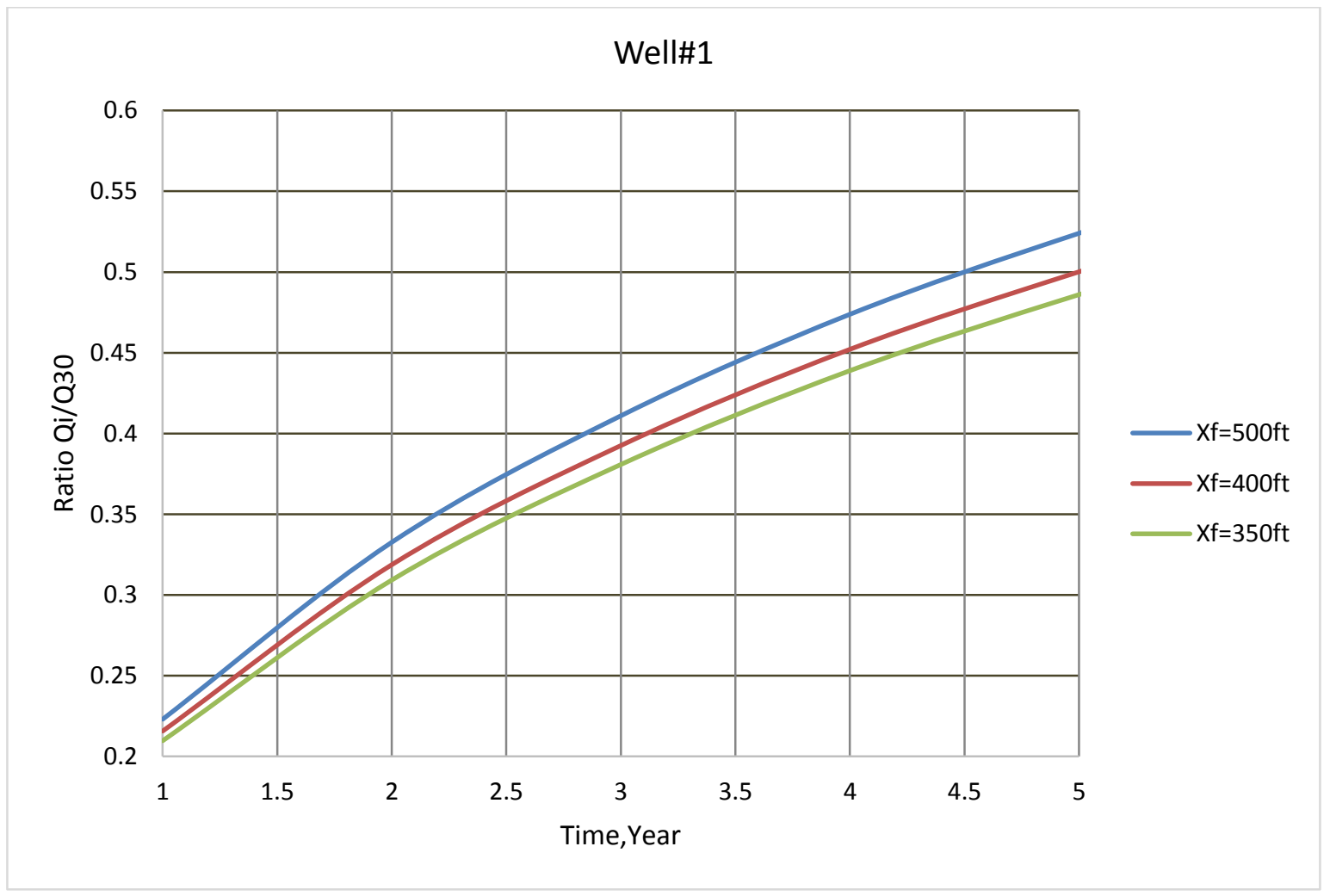

Figure 4-3 Impact of $X_{f}$ on the production ratio 


\section{4-2-2 The Impact of the Fracture permeability $\left(k_{f}\right)$ and the number of fractures}

In this well, the value of natural fracture permeability and number of fractures were changed while the other factors remained constant to observe its impact on the correlation. This investigation found out that, fracture permeability doesn't affect the ratio while the ratio increases as the number of fractures increases. Figure 4-4 illustrates the impact of $\left(k_{f}\right)$ and number of fracture on the ratio.

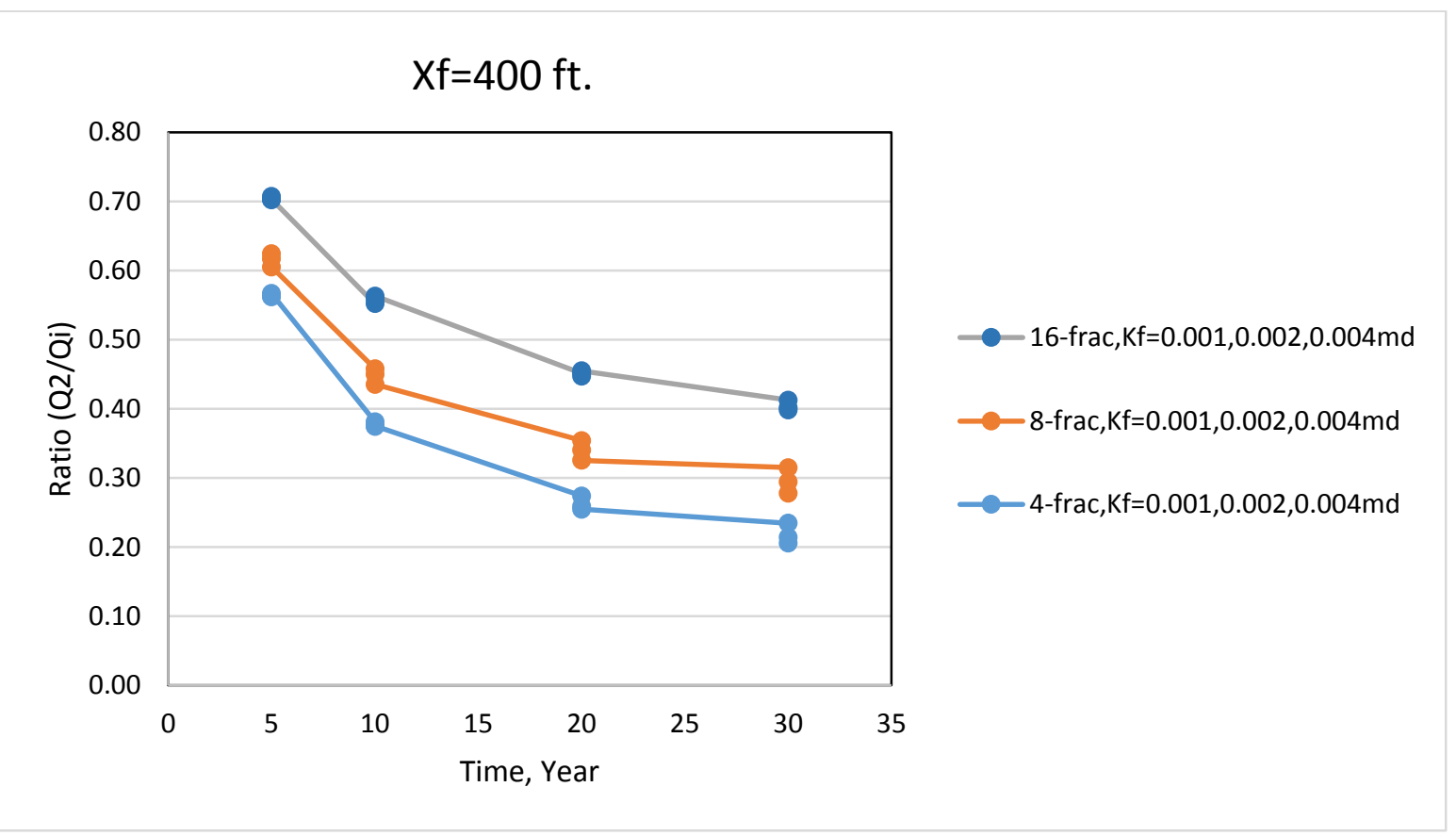

Figure 4-4 Impact of fracture permeability and number of fractures on the ratio 


\section{4-2-3 The Impact of Matrix porosity}

Matrix porosity was changed for different fracture half length. This correlation was not affected by the different porosity values. Figure 4-5 illustrates the impact of matrix porosity on the ratio. The rest of the figures are in Appendix A.

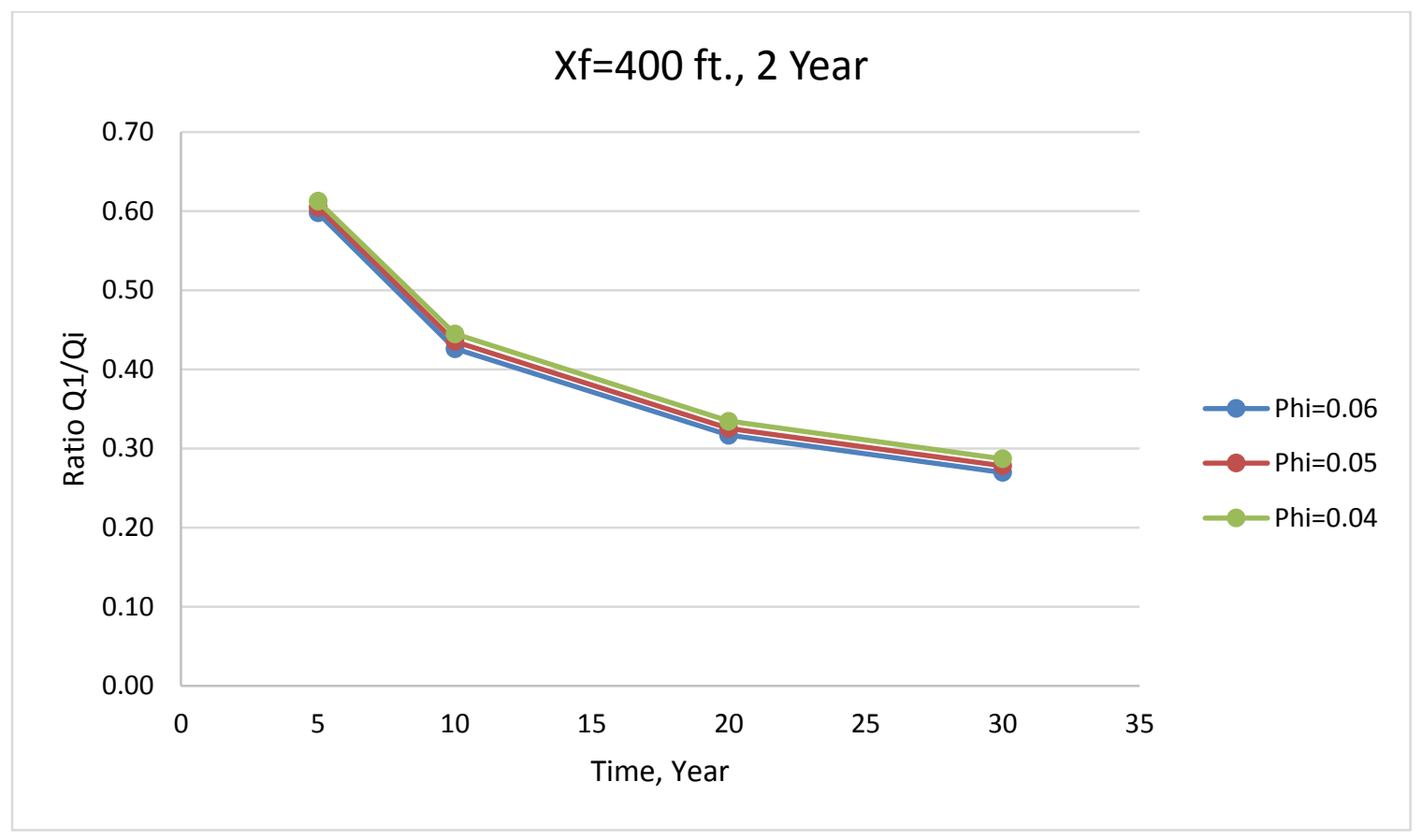

Figure 4-5 Impact of matrix porosity on the ratio 


\section{4-3 Evaluation of the correlation}

The predicted ultimate gas recoveries for 2 horizontal Marcellus shale wells based on the actual production data using the correlation were compared against the predicted ultimate gas recoveries from the history matched models. The history matching and the results for Well \#2 are shown in Figure 4-6 and Table 4-2 respectively. Figure A-1 and Figure A-2 that were used to get the ratio are in Appendix A.

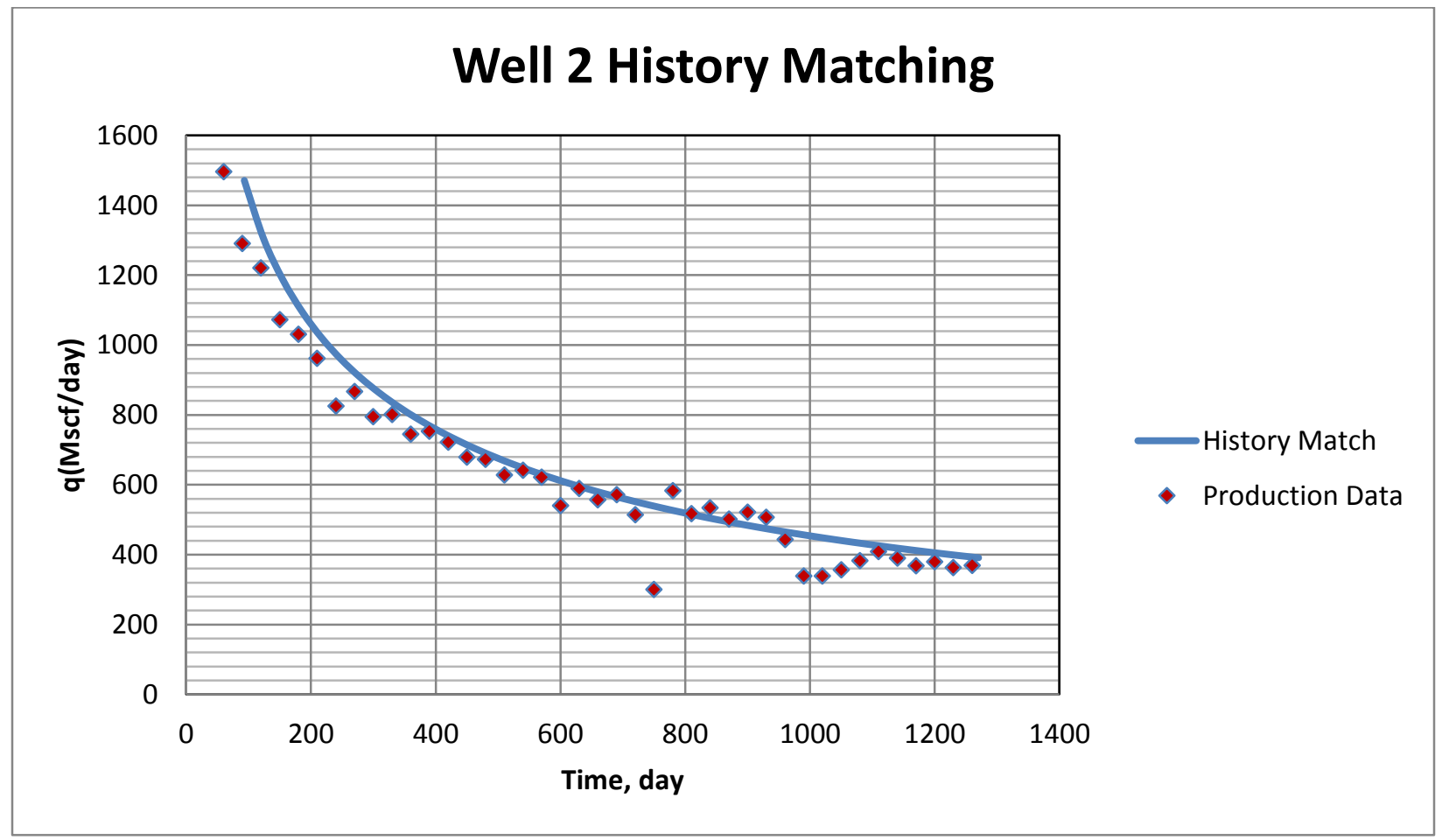

Figure 4-6 History matching for horizontal well \#2

Table 4-2 Results of the correlation predictions for Well \#2

\begin{tabular}{|c|c|c|c|c|c|}
\hline Year & $\begin{array}{c}\text { Qi, } \\
\text { MMcf }\end{array}$ & Qi/Q30 & $\begin{array}{c}\text { Predicted Q30 } \\
\text { From the } \\
\text { correlation, } \\
\text { MMcf }\end{array}$ & $\begin{array}{c}\text { Predicted Q30 } \\
\text { From the } \\
\text { History } \\
\text { Matching, MMcf }\end{array}$ & Error \% \\
\hline 1 & 347 & 0.143 & 2,435 & 2,543 & 4.25 \\
\hline 2 & 572 & 0.222 & 2,575 & 2,543 & -1.23 \\
\hline
\end{tabular}


The history matching and the results for well \#3 are shown in Figure 4-7 and Table 4-3 respectively. Figure A-3 and A-4 that were used to get the ratio are in Appendix A.

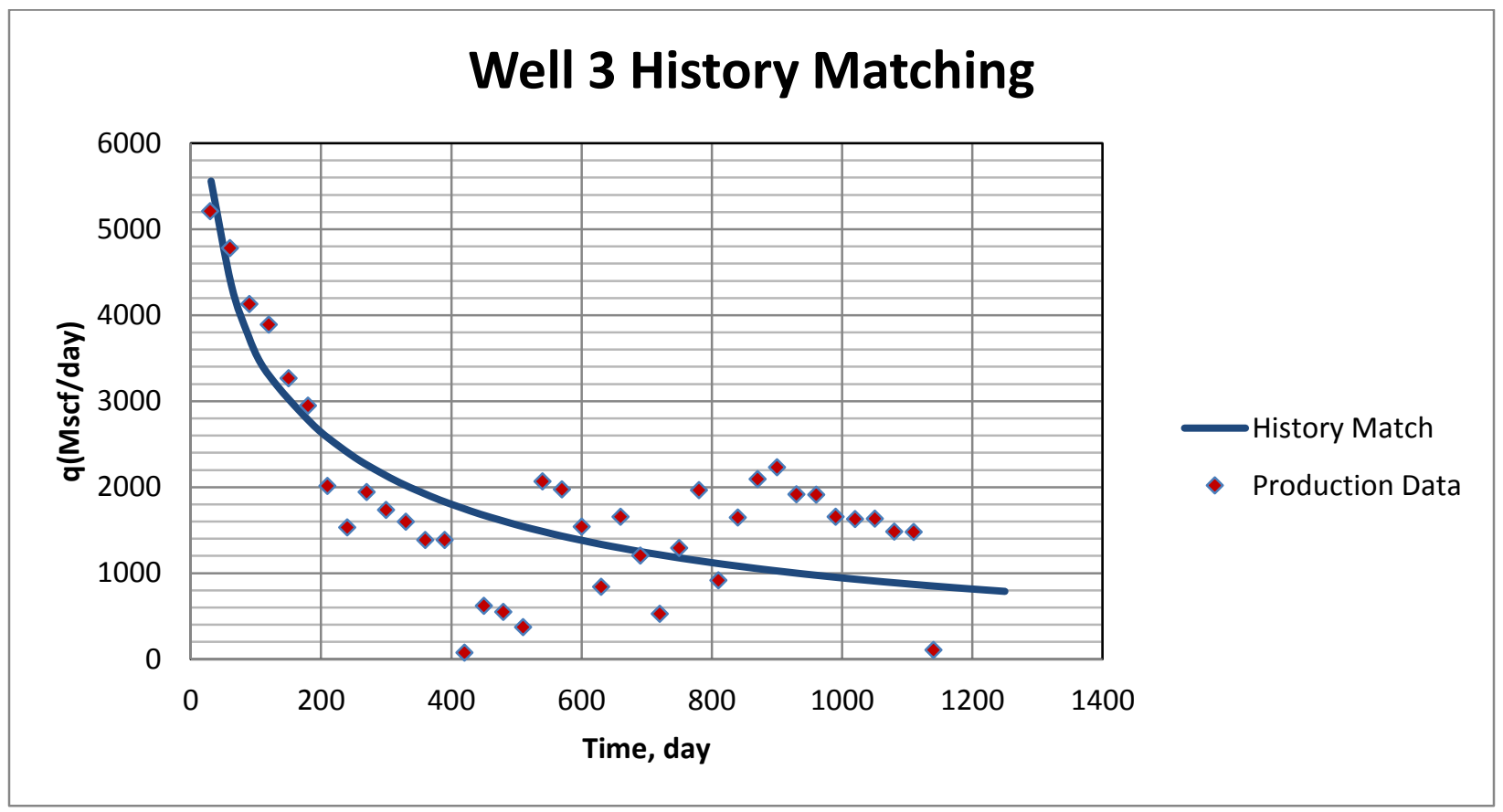

Figure 4-7 History matching for horizontal well \#3

Table 4-3 Results of the correlation predictions for Well \#3

\begin{tabular}{|c|c|c|c|c|c|}
\hline Year & $\begin{array}{c}\text { Qi, } \\
\text { MMcf }\end{array}$ & Qi/Q30 & $\begin{array}{c}\text { Predicted Q30 } \\
\text { From the } \\
\text { correlation, } \\
\text { MMcf }\end{array}$ & $\begin{array}{c}\text { Predicted Q30 } \\
\text { From the } \\
\text { History } \\
\text { Matching, MMcf }\end{array}$ & Error \% \\
\hline 1 & 1,034 & 0.168 & 6,172 & 4,209 & 31.8 \\
\hline 2 & 1,419 & 0.263 & 5,407 & 4,209 & 22.2 \\
\hline
\end{tabular}




\section{CHAPTER 5}

\section{Conclusion}

1. The number of fracture stages has significant impact on the production ratio correlation.

2. In the early period of production the fracture half-length does not have significant impact on the production since the production originates from the areas at distances shorter than the fracture half-length from the wellbore.

3. During the late production period, the fracture half-length has more impact on production since the production come from areas beyond the tip of the fracture.

4. The natural fracture permeability and the matrix porosity do not have significant impacts on the ratio.

5. The comparison of the predicted ultimate gas recovery by the production ratio correlation and the predicted ultimate gas recovery by history match with the reservoir model indicate that reliable estimates of gas ultimate recovery can be obtained by the use of the production ratio correlation. 


\section{References}

- Economides M.J. Fracturing Horizontal Transverse, Horizontal Longitudinal and Vertical Wells: Criteria for Decision. Paper CSUG/SPE 137328.

- Fekete, Flow Regimes", www.fekete.com/software/welltest/media/webhelp/c-teflowregimes.htm: “

- Geology, 2012, "Marcellus shale - Appalachian Basin," http://geology.com/articles/ marcellus-shale.shtml

- Gidley, J.L. et al., 1989: Recent Advances in Hydraulic Fracturing, Monograph Series, SPE, Richardson, Texas 12, 1-2, 83-89, 95-106

- Joshi, S.D., 1987: "A Review of Horizontal Well and drainhole Technology," paper SPE 16868, SPE Annual Technical Conference and Exhibition, Dallas, Sep. 27-30.

- Joshi, S.D., 1988: "Augmentation of well productivity using slant and horizontal wells", Journal of Petroleum Technology, Vol. 40, pp. 729-739.

- Masters J.A., 1979: "Deep Basin Gas Trap, Western Canada,"AAPG Bulletin 63, No. 2: 152.

- Schlumberger Wireline \& Testing 1998, Introduction to Well Testing, Bath, England.

- Schlumberger, 2010: Eclipse Reservoir Engineering Software Manual.

- Soliman, M.Y. Hunt, J.L., and Azari, M., 1999 "Fracturing Horizontal Wells in Gas Reservoirs," paper SPE 59096

- Song, B., Economides, M.J., and Ehlig-Economides, C. 2011. "Design of Transverse Fracture Horizontal Wells in Shale Gas Reservoirs," Paper SPE 140555, SPE Hydraulic Fracturing Technology Conference and Exhibition held in the Woodlands, Texas, USA, 24-26 January 2011. DOI: 10.2118/140555-MS.

- Tschirhart, N.R., 2005: "The Evaluation of Waterfrac Technology in Low-Permeability Gas Sands in the East Texas Basin," MS thesis, Texas A\&M U., College Station, Texas.

- U.S. Energy Information Administration, 2012, "Annual Energy Outlook 2011 with Projections to 2035," U.S. Department of Energy. Washington, D.C. 


\section{Appendix A}

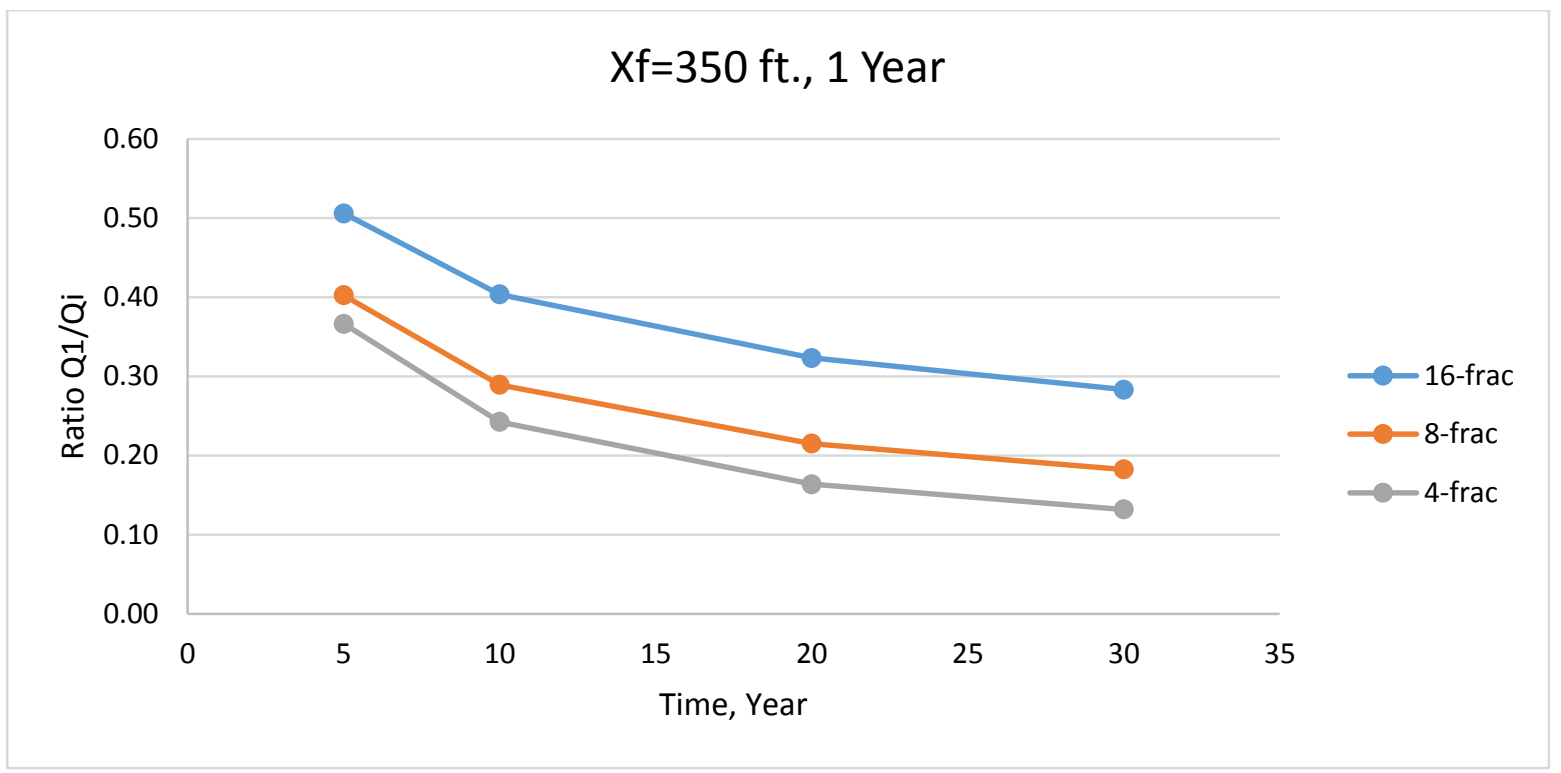

Figure A-1 Correlation Q1/Qi (Xf=350ft.)

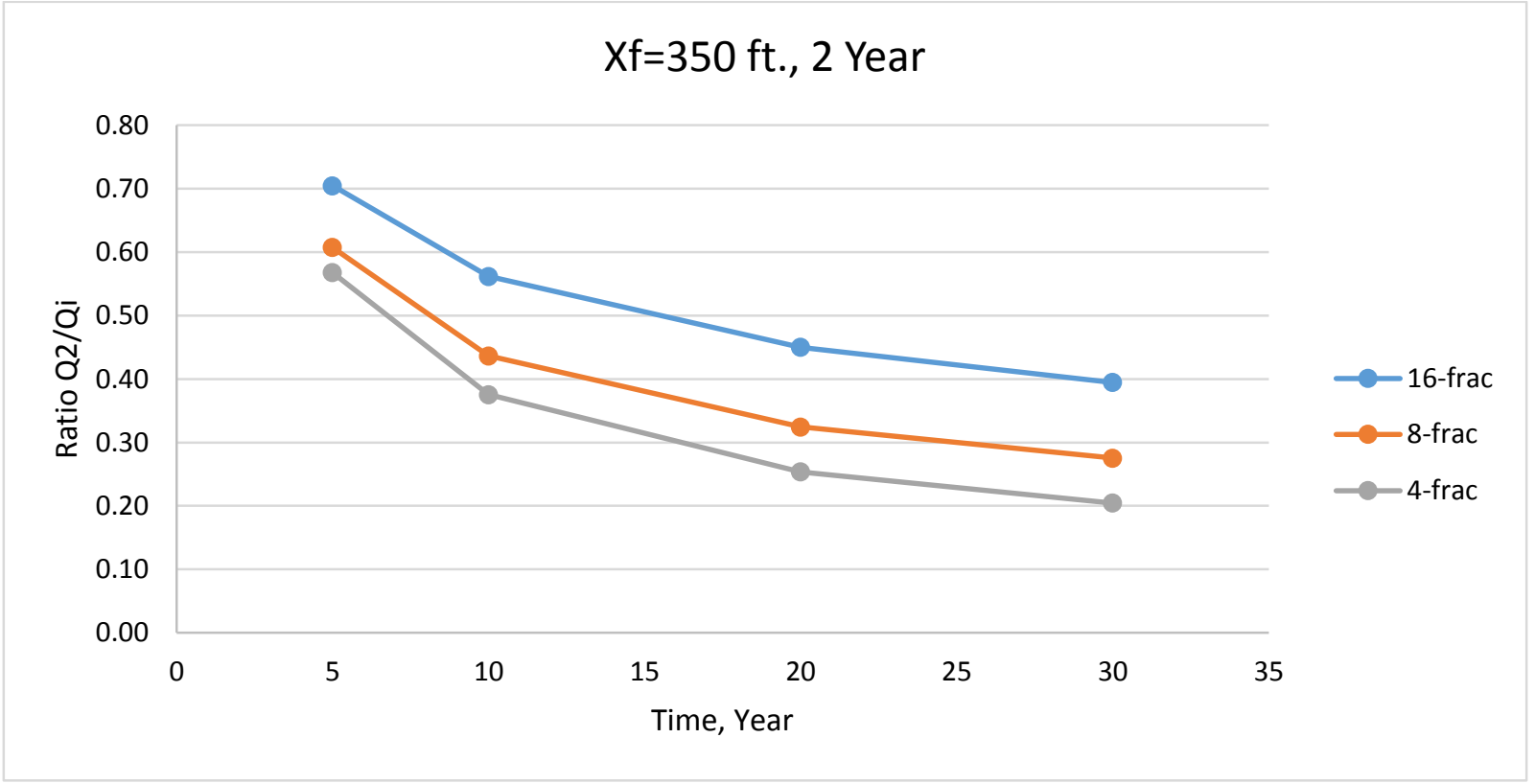

Figure A-2 Correlation Q2/Qi (Xf=350ft.) 


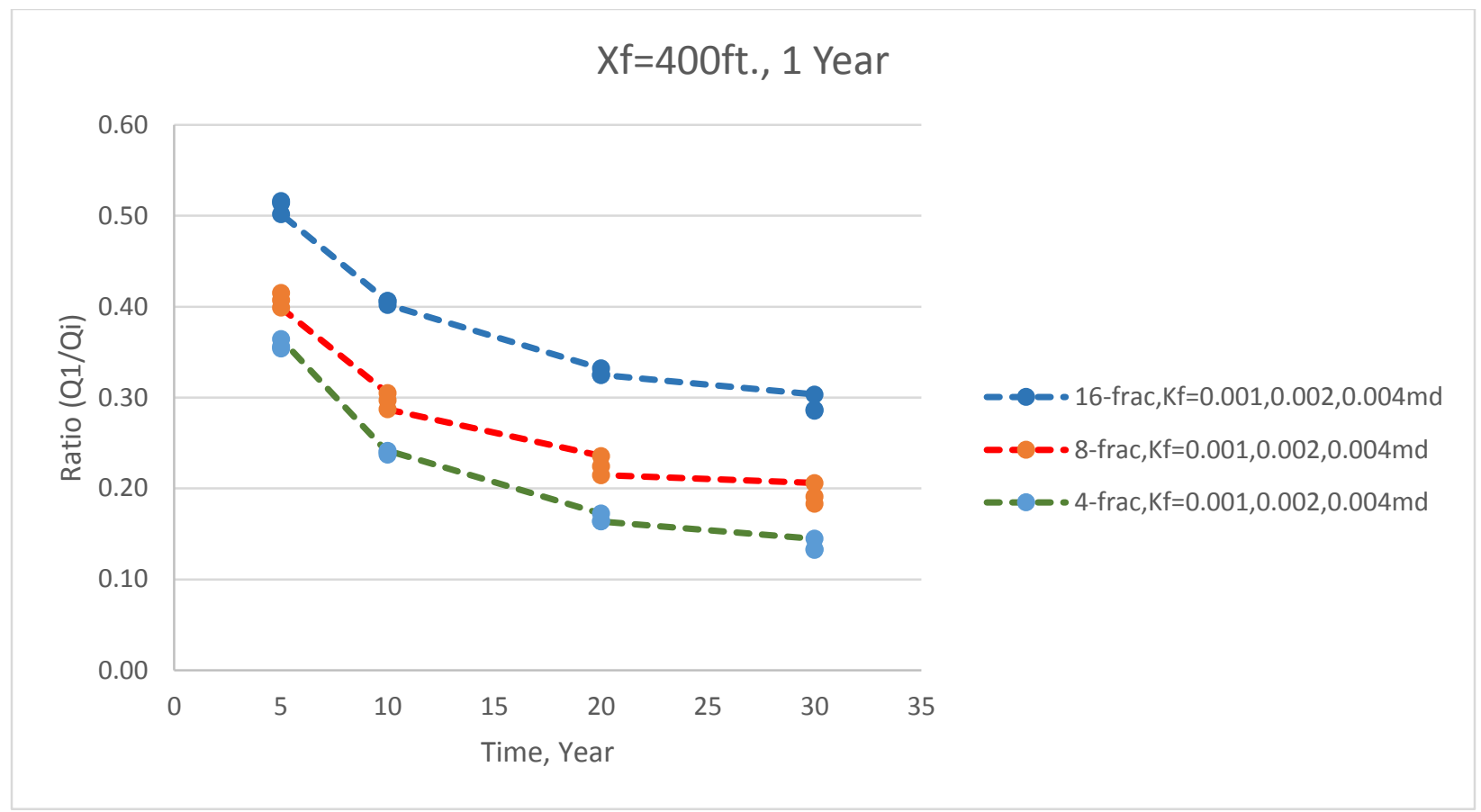

Figure A-3 Correlation Q1/Qi (Xf=400 ft.)

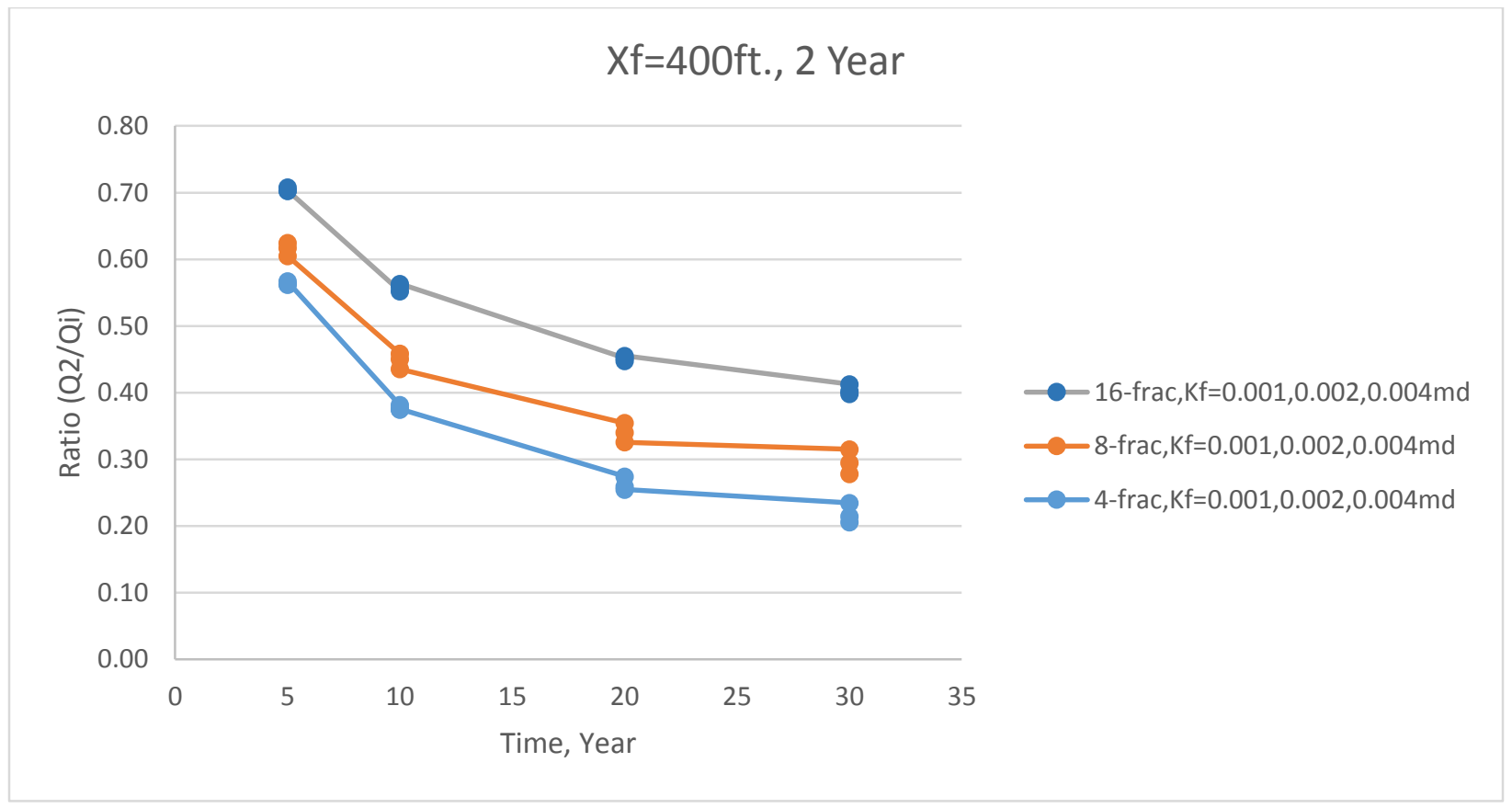

Figure A-4 Correlation Q2/Qi (Xf=400ft.) 


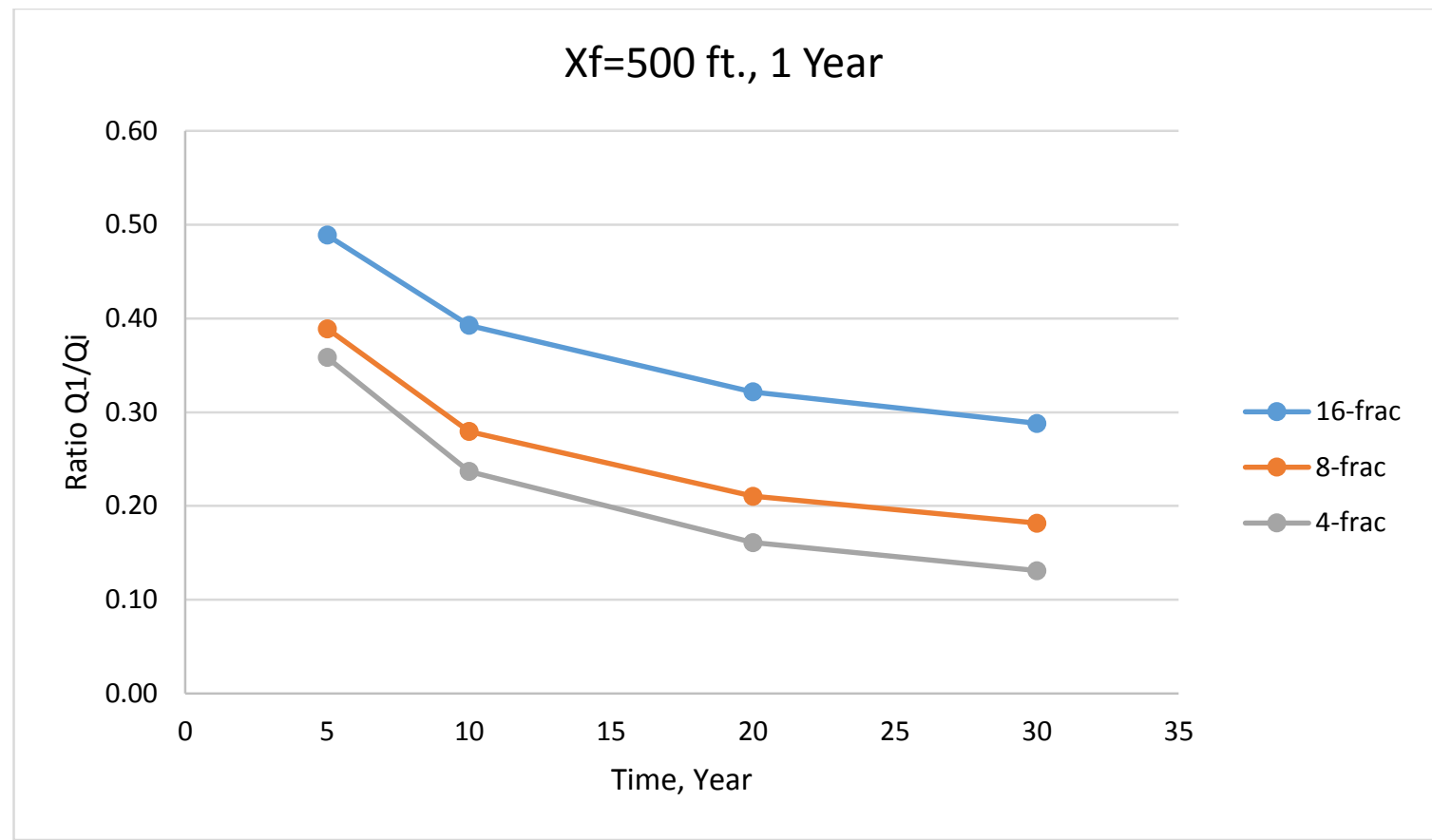

Figure A-5 Correlation Q1/Qi ( $\mathrm{Xf}=500 \mathrm{ft}$.)

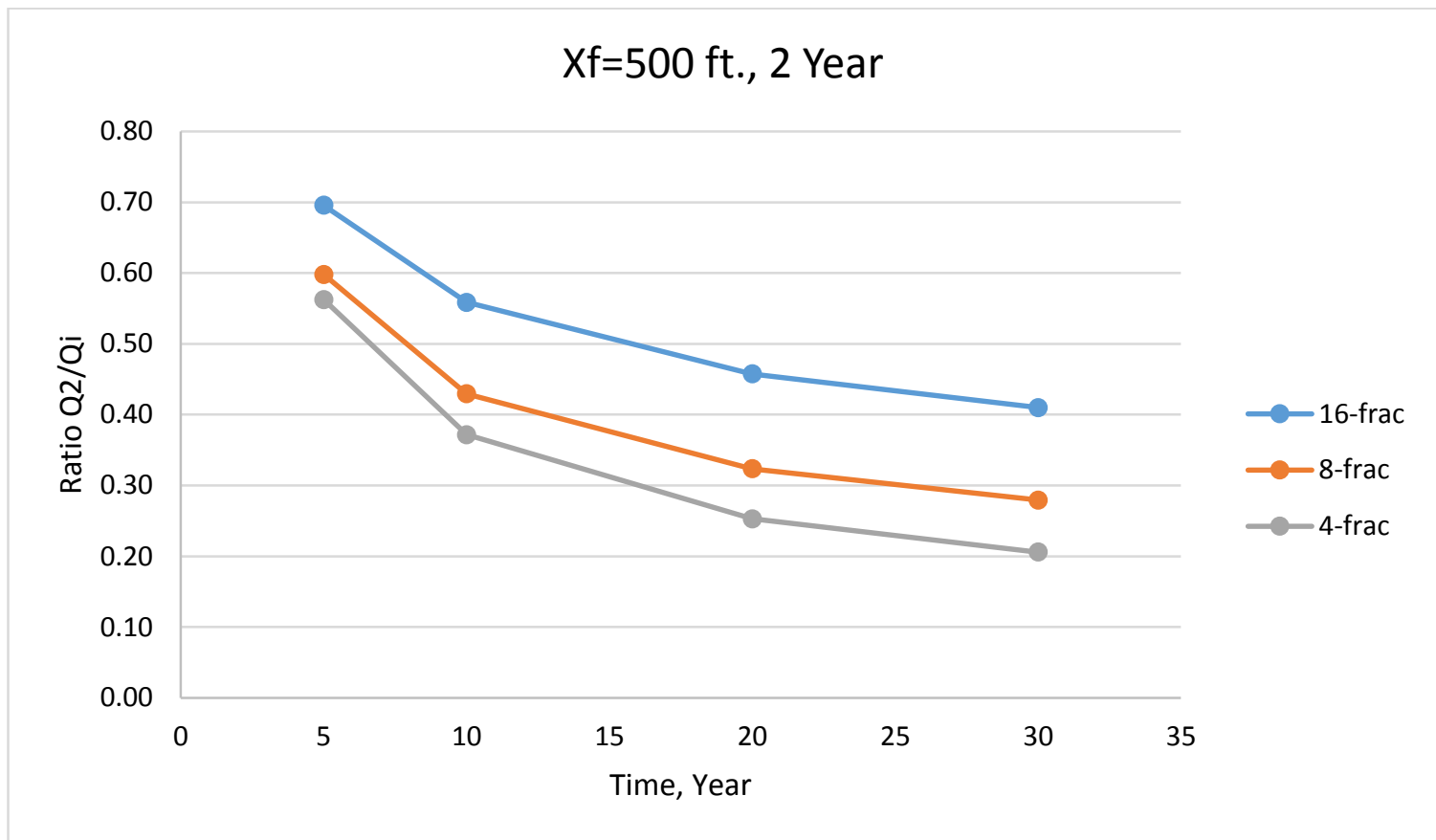

Figure A-6 Correlation Q2/Qi ( $\mathrm{Xf}=500 \mathrm{ft}$.) 